\title{
Description of a new species of Loxosceles Heineken \& Lowe (Araneae, Sicariidae) recluse spiders from Hidalgo, Mexico, under integrative taxonomy: morphological and DNA barcoding data (CO1 + ITS2)
}

\author{
Claudia Isabel NAVARRO-RODRÍGUEZ ${ }^{1} \&$ Alejandro VALDEZ-MONDRAGÓN ${ }^{2, *}$ \\ ${ }^{1}$ Laboratory of Arachnology (LATLAX), Laboratorio Regional de Biodiversidad y Cultivo de Tejidos \\ Vegetales (LBCTV), Instituto de Biología, Universidad Nacional Autónoma de Mexico (UNAM), \\ sede Tlaxcala, Ex-Fábrica San Manuel, San Miguel Contla, 90640 Santa Cruz Tlaxcala, \\ Tlaxcala, Mexico. \\ ${ }^{1}$ Posgrado en Ciencias Biológicas, Centro Tlaxcala de Biología de la Conducta (CTBC), Universidad \\ Autónoma de Tlaxcala (UATx), Carretera Federal Tlaxcala-Puebla, Km. 1.5, C. P. 90062 , \\ Tlaxcala, Mexico. \\ ${ }^{2}$ CONACYT Research Fellow. Laboratory of Arachnology (LATLAX), Laboratorio Regional de \\ Biodiversidad y Cultivo de Tejidos Vegetales (LBCTV), Instituto de Biología, Universidad Nacional \\ Autónoma de Mexico (UNAM), sede Tlaxcala, Ex-Fábrica San Manuel, San Miguel Contla, 90640 \\ Santa Cruz Tlaxcala, Tlaxcala, Mexico. \\ ${ }^{2}$ Colección Nacional de Arácnidos (CNAN), Departamento de Zoología, Instituto de Biología, \\ Universidad Nacional Autónoma de Mexico (UNAM), Ciudad Universitaria, Apartado Postal 04510, \\ Coyoacán, Mexico City, Mexico. \\ "Corresponding author: lat_mactans@yahoo.com.mx \\ 1Email: biobella66@hotmail.com \\ ${ }^{1}$ urn:1sid:zoobank.org:author:B3AD9D20-D15E-4363-8A04-88C1C2F9374E \\ ${ }^{2}$ urn:lsid:zoobank.org:author:F043A1C7-2B83-40C9-A74E-82C92F00725A
}

\begin{abstract}
Based on an integrative taxonomic approach, a new species of the genus Loxosceles Heineken \& Lowe, 1832, is described from the state of Hidalgo, Mexico. Loxosceles tolantongo sp. nov. is described based on DNA barcoding using cytochrome $c$ oxidase subunit 1 (COI) and internal transcribed spacer 2 (ITS2), and morphology. For species delimitation, four molecular methods were implemented: 1) corrected $p$-distances under neighbor joining (NJ); 2) automatic barcode gap discovery (ABGD); 3) general mixed yule coalescent model (GMYC) and 4) Bayesian Poisson tree processes (bPTP). The new species morphologically resembles $L$. jaca, another species from Hidalgo, but there are morphological differences mainly in the tibiae of the male palp, the seminal receptacles of the females and also the high genetic $p$-distances. $\mathrm{CO1}$ was more informative than ITS2 for the genetic separation; however, both concatenated genes $(C O 1+I T S 2)$ present robust evidence for species delimitation. Loxosceles tolantongo sp. nov. is considered a unique species for four reasons: 1) it can be diagnosed and distinguished by morphological characters (of the male palps mainly, but also of the seminal receptacles of the females); 2) the genetic $p$-distances with $C O 1$ were high $(>10 \%) ; 3)$ the molecular species delimitation methods were congruent under $\mathrm{CO1}$ and $\mathrm{CO1}+\mathrm{ITS2}$; and 4) under $\mathrm{CO1}$ and $C O 1+I T S 2$, the new species is a putative sister group of L. jaca $+L$. tenango.
\end{abstract}


Keywords. Integrative taxonomy, molecular markers, Synspermiata, species delimitation, Hidalgo.

Navarro-Rodríguez C.I. \& Valdez-Mondragón A. 2020. Description of a new species of Loxosceles Heineken \& Lowe (Araneae, Sicariidae) recluse spiders from Hidalgo, Mexico, under integrative taxonomy: morphological and DNA barcoding data (CO1+ITS2). European Journal of Taxonomy 704: 1-30. https://doi.org/10.5852/ejt.2020.704

\section{Introduction}

Spiders of the genus Loxosceles Heineken \& Lowe, 1832 are better known as 'violin spiders', 'recluse spiders' or 'brown recluse spiders', and there are currently 139 species worldwide (World Spider Catalog 2020). Gertsch $(1958,1967)$ and Gertsch \& Ennik (1983) proposed that the species of Loxosceles belong to eight species groups: reclusa, laeta, amazonica, gaucho, spadicea, rufescens, vonwredei and spinulosa. However, Duncan et al. (2010) and Fukushima et al. (2017) synonymized the species group amazonica with the species group rufescens based on molecular data. Therefore, the genus is currently composed of seven species groups (Valdez-Mondragón et al. 2019). North America is the region that has the highest diversity with more than 50 species, all of them belonging to the reclusa species group and distributed mainly in Mexico (Gertsch \& Ennik 1983; Valdez-Mondragón et al. 2018 b 2019). Mexico is the country with the highest diversity of species worldwide, with a total of 39 species described, 37 native species and two introduced: Loxosceles reclusa Gertsch \& Mulaik, 1940 and Loxosceles rufescens (Dufour, 1820) (Gertsch 1958, 1973; Gertsch \& Ennik 1983; Valdez-Mondragón et al. 2018a, 2018b). Baja California Sur, Baja California and Sonora are the states with the greatest diversity in the country, with five species each (Valdez-Mondragón et al. 2018a, 2018b). The preferred habitats of the species of Loxosceles from Mexico are mainly dry and tropical forests, including tropical deciduous forests, and deserts; however, some species, such as L. chinateca Gertsch \& Ennik, 1983 and L. yucatana Chamberlin \& Ivie, 1938, are distributed exclusively in tropical rain forests (ValdezMondragón et al. 2019). Also, some species have been recorded from caves, a preferred microhabitat of some species, e.g., L. misteca Gertsch, 1958, L. boneti Gertsch, 1958, L. chinateca, L. tehuana Gertsch, 1958, L. tenango Gertsch, 1973 and L. yucatana (Valdez-Mondragón et al. 2018a, 2018b, 2019). In the last two years, two species have been described from Mexico, Loxosceles malintzi Valdez-Mondragón, Cortez-Roldán, Juárez-Sánchez \& Solís-Catalán, 2018 from the states of Puebla, Morelos and Guerrero; and Loxosceles tenochtitlan Valdez-Mondragón \& Navarro-Rodríguez, 2019 from Mexico City, and the states of Mexico and Tlaxcala (Valdez-Mondragón et al. 2018a, 2018b, 2019).

Historically, the taxonomy of spiders has been based mainly on traditional morphology, using genitalic characters, such as male palps and seminal receptacles in females. Sexual characters in spiders are robust and important morphological characters that are still used to separate species and to provide a diagnosis. This means that genitalia evolves, on average, more rapidly than non-genital morphological traits (Huber 2003; Huber \& Dimitrov 2014). Furthermore, somatic characters are useful as additional evidence to separate species in some groups of spiders. Thus coloration, color pattern, body proportions and even extreme size differences are useful traits for species separation (Huber et al. 2005; Huber \& Dimitrov 2014; Valdez-Mondragón et al. 2019). Traditional morphology alone cannot determine species boundaries in some cases due to the intraspecific variation in sexual structures, and the genus Loxosceles is a good example (Brignoli 1968; Gertsch \& Ennik 1983; Valdez-Mondragón et al. 2019). However, the male palps of Loxosceles remain a good character for species identification because of the little morphological variation in comparison with the seminal receptacles of the females, as was demonstrated recently in the description of L. malintzi and L. tenochtitlan by Valdez-Mondragón et al. (2018b, 2019).

In spider groups with complicated morphology, the use of molecular markers helps in the discovery of undescribed diversity and species delimitation, as was demonstrated, for example, by Planas \& Ribera (2015) with the genus Loxosceles. Although DNA barcodes are being applied in systematics as a 
useful tool to resolve species delimitation problems, modern taxonomy includes many different sources of evidence, such as traditional morphology, ecology, reproduction and biogeography (integrative taxonomy). Recently described L. tenochtitlan by Valdez-Mondragón et al. (2019) represents the first species of the genus described using an integrative taxonomic approach with multiple lines of evidence, including traditional morphology, geometric and lineal morphology, molecular markers (CO1 and ITS2), and even the biogeographic methods of ecological niche modeling.

In this study, a new species of Loxosceles from the state of Hidalgo is described based on morphological and molecular evidence using an integrative taxonomic approach.

\section{Material and methods}

\section{Biological material}

Specimens were hand-collected and preserved in ethanol (80\%) for morphology and ethanol (96\%) for molecular studies. The type specimens and the additional examined material are deposited in the following repositories:
CNAN = National Collection of Arachnids, Institute of Biology, Universidad Nacional Autónoma de Mexico (IBUNAM), Mexico City, Mexico (type specimens).
LATLAX = Laboratory of Arachnology, Laboratorio Regional de Biodiversidad y Cultivo de Tejidos Vegetales (LBCTV), IBUNAM, Tlaxcala City, Mexico (additional material).

Descriptions and observations of the specimens were done using a Zeiss Discovery V8 stereo microscope. The digital photographs of the specimens were taken with a Zeiss Axiocam 506 color camera attached to a Zeiss AXIO Zoom V16 stereo microscope. Photographs were edited using Photoshop CS6. The male palps and female genitalia were dissected in ethanol (80\%). The female genitalia were cleaned in potassium hydroxide $(\mathrm{KOH}-10 \%)$ for 5 to 10 minutes, following Valdez-Mondragón et al. (2018b) protocol. The habitus, male palps and female genitalia were submerged in $96 \%$ alcohol gel (ethanol) and covered with a thin layer of distilled water to minimize diffraction during photography (ValdezMondragón \& Francke 2015; Valdez-Mondragón et al. 2019). The descriptions were done following Valdez-Mondragón et al. (2018b, 2019). All morphological measurements are given in millimeters (mm). The distribution map was made using Q-QGIS ver. 2.18.
Abbreviations
$\mathrm{AME}=$ anterior median eyes
PLE $=$ posterior lateral eyes
$\mathrm{PME}=$ posterior median eyes

\section{Taxon sampling}

The molecular analyses presented here are based on a total of 50 individuals from eleven species, including the new species described here and two outgroups to root the trees: Loxosceles rufescens (Dufour, 1820) and Scytodes thoracica (Latreille, 1802) (Table 1). Three different partitions were used (CO1: 674 bp, ITS2: 435 bp and CO1 + ITS2: 1109 bp).

\section{DNA extraction, amplification and sequencing}

Specimens for DNA extraction were preserved in ethanol $(96 \%)$ and kept at $-20^{\circ} \mathrm{C}$. DNA was isolated from legs, prosoma, or complete specimens in the case of immatures. DNA extractions were done using a Qiagen DNeasy Tissue Kit following the protocol by Valdez-Mondragón et al. (2019). DNA fragments included approximately $650 \mathrm{bp}$ of the cytochrome $c$ oxidase subunit 1 (CO1) mitochondrial gene and $435 \mathrm{bp}$ of the Internal Transcribed Spacer 2 (ITS2) nuclear gene. The fragments were amplified 
Table 1 (continued on the next page). Specimens sequenced for each species of Loxosceles Heineken \& Lowe, 1832 and Scytodes Latreille, 1804, DNA voucher numbers, localities and GenBank accession numbers.

\begin{tabular}{|c|c|c|c|c|}
\hline \multirow[t]{2}{*}{ Species } & \multirow{2}{*}{$\begin{array}{l}\text { DNA voucher } \\
\text { LATLAX }\end{array}$} & \multirow[t]{2}{*}{ Locality } & \multicolumn{2}{|c|}{ GenBank accession number } \\
\hline & & & CO1 & ITS2 \\
\hline L. colima & Ara0115 & Mexico: Colima & MK936303 & MK957224 \\
\hline L. colima & Ara0280 & Mexico: Colima & MN512430 & MN525282 \\
\hline L. colima & Ara0281 & Mexico: Colima & - & MN525283 \\
\hline L. colima & Ara0282 & Mexico: Colima & MN512431 & - \\
\hline L. colima & Ara0283 & Mexico: Colima & MN512432 & MN525284 \\
\hline L. jaca & Ara0186 & Mexico: Hidalgo & MK936292 & MK957194 \\
\hline L. jaca & Ara0048 & Mexico: Hidalgo & MK936293 & - \\
\hline L. jaca & Ara0046 & Mexico: Hidalgo & MN512427 & MK957192 \\
\hline L. jaca & Ara0047 & Mexico: Hidalgo & MN512428 & MK957193 \\
\hline L. jaca & Ara0183 & Mexico: Hidalgo & MN512429 & MK957199 \\
\hline L. malintzi & Ara0100 & Mexico: Guerrero & MK936282 & MK957220 \\
\hline L. malintzi & Ara0001 & Mexico: Puebla & MK936283 & MK957218 \\
\hline L. malintzi & Ara0002 & Mexico: Puebla & MK936284 & - \\
\hline L. malintzi & Ara0025 & Mexico: Puebla & MK936285 & MK957219 \\
\hline L. malintzi & Ara0072 & Mexico: Puebla & MK936286 & MK957222 \\
\hline L. malintzi & Ara0074 & Mexico: Puebla & MK936287 & MK957223 \\
\hline L. malintzi & Ara0101 & Mexico: Guerrero & MK936288 & - \\
\hline L. malintzi & Ara0004 & Mexico: Puebla & MK936289 & MK957221 \\
\hline L. misteca & Ara0082 & Mexico: Guerrero & MK936272 & MK957212 \\
\hline L. misteca & Ara0089 & Mexico: Guerrero & MK936273 & MK957215 \\
\hline L. misteca & Ara0090 & Mexico: Guerrero & MK936274 & MK957214 \\
\hline L. misteca & Ara0084 & Mexico: Guerrero & MK936275 & MK957213 \\
\hline L. misteca & Ara0236 & Mexico: Guerrero & MK936276 & MN525280 \\
\hline L. misteca & Ara0237 & Mexico: Guerrero & MK936277 & MN525281 \\
\hline L. nahuana & Ara0076 & Mexico: Hidalgo & MK936297 & MK957216 \\
\hline L. nahuana & Ara0077 & Mexico: Hidalgo & MK936298 & - \\
\hline L. nahuana & Ara0079 & Mexico: Hidalgo & MK936299 & MK957217 \\
\hline L. tenango & Ara0191 & Mexico: Hidalgo & MK936290 & - \\
\hline L. tenango & Ara0192 & Mexico: Hidalgo & MK936291 & MK957201 \\
\hline L. tenango & Ara0045 & Mexico: Hidalgo & - & MK957195 \\
\hline L. tenango & Ara0189 & Mexico: Hidalgo & - & MK957196 \\
\hline L. tenango & Ara0190 & Mexico: Hidalgo & - & MK957197 \\
\hline L. tenango & Ara0193 & Mexico: Hidalgo & - & MK957198 \\
\hline L. tenango & Ara0188 & Mexico: Hidalgo & - & MK957200 \\
\hline L. tenochtitlan & Ara0146 & Mexico: Mexico City & MK936278 & MK957209 \\
\hline L. tenochtitlan & Ara0161 & Mexico: Mexico City & MK936279 & - \\
\hline L. tenochtitlan & Ara0173 & Mexico: Tlaxcala & MK936280 & MK957210 \\
\hline L. tenochtitlan & Ara0164 & Mexico: Tlaxcala & MK936281 & MK957211 \\
\hline
\end{tabular}


Table 1 (continued). Specimens sequenced for each species of Loxosceles Heineken \& Lowe, 1832 and Scytodes Latreille, 1804, DNA voucher numbers, localities and GenBank accession numbers.

\begin{tabular}{lllll}
\hline Species & DNA voucher & Locality & \multicolumn{2}{l}{ GenBank accession number } \\
\cline { 4 - 5 } & LATLAX & & CO1 & ITS2 \\
\hline L. tolantongo sp. nov. & Ara0175 & Mexico: Hidalgo & MK936294 & MK957208 \\
L. tolantongo sp. nov. & Ara0181 & Mexico: Hidalgo & MK936295 & MK957206 \\
L. tolantongo sp. nov. & Ara0182 & Mexico: Hidalgo & MK936296 & MK957207 \\
L. tolantongo sp. nov. & Ara0174 & Mexico: Hidalgo & - & MK957202 \\
L. tolantongo sp. nov. & Ara0176 & Mexico: Hidalgo & - & MK957203 \\
L. tolantongo sp. nov. & Ara0177 & Mexico: Hidalgo & - & MK957204 \\
L. tolantongo sp. nov. & Ara0178 & Mexico: Hidalgo & - & MK957205 \\
L. zapoteca & Ara0094 & Mexico: Guerrero & MK936300 & MK957225 \\
L. zapoteca & Ara0220 & Mexico: Guerrero & MK936301 & MN525285 \\
L. zapoteca & Ara0227 & Mexico: Guerrero & MK936302 & MN525286 \\
L. rufescens & - & Grecia: Peloponeso & - & KR864735 \\
Scytodes thoracica & - & Turquía: Antalya & KR864739 & - \\
\hline
\end{tabular}

using the primers in Table 2. Amplifications were carried out in a Veriti Applied-Biosystems 96 Well Thermal Cycler, in a total volume of $25 \mu \mathrm{l}: 3 \mu \mathrm{l}$ DNA, $8.7 \mu \mathrm{H}_{2} \mathrm{O}, 12.5 \mu \mathrm{l}$ Multiplex PCR Kit of QIAGEN and $0.4 \mu \mathrm{l}$ of each molecular marker (forward and reverse). The PCR program for $\mathrm{CO} 1$ was as follows: initial step $1 \mathrm{~min}$ at $95^{\circ} \mathrm{C}$; amplification 35 cycles of $30 \mathrm{~s}$ at $95^{\circ} \mathrm{C}$ (denaturation), $30 \mathrm{~s}$ at $48^{\circ} \mathrm{C}$ (annealing), $1 \mathrm{~min}$ at $72^{\circ} \mathrm{C}$ (elongation); and final elongation $5 \mathrm{~min}$ at $72^{\circ} \mathrm{C}$. PCR program for ITS2 was as follows: initial step $3 \mathrm{~min}$ at $94^{\circ} \mathrm{C}$; amplification 40 cycles of $30 \mathrm{~s}$ at $94^{\circ} \mathrm{C}$ (denaturation), $1 \mathrm{~min}$ at $53^{\circ} \mathrm{C}$ (annealing), $1 \mathrm{~min}$ at $72^{\circ} \mathrm{C}$ (elongation); and final elongation $5 \mathrm{~min}$ at $72^{\circ} \mathrm{C}$. PCR products were checked to analyze length and purity on $1 \%$ agarose gels with a marker of $100 \mathrm{bp}$ and purified directly using the QIAquick PCR Purification kit of QIAGEN. DNA extraction and amplification were performed at the Molecular Laboratory at the Laboratorio Regional de Biodiversidad y Cultivo de Tejidos Vegetales (LBCTV), Institute of Biology, Universidad Nacional Autónoma de Mexico (UNAM), Tlaxcala City. Sequencing was performed at the Molecular Laboratory in the Institute of Biology, UNAM, Mexico City. Sequencing of both strands $\left(5^{\prime}-3^{\prime}\right.$ and $\left.3^{\prime}-5^{\prime}\right)$ of PCR products were performed in a Sequencer Genetic Analyzer RUO Applied Biosystems Hitachi model 3750xL. Sequence data of CO1 and ITS2 are deposited in GenBank with accession numbers: MK936272-MK936303 and MN512427-MN512432 for CO1 and MK957192-MK957225 and MN525280-MN525286 for ITS2 (Table 1).

\section{DNA sequence alignment and editing}

Sequences were edited with the programs BioEdit ver. 7.0.5.3 (Hall 1999) and Geneious ver. 10.2.3 (Kearse et al. 2012). Sequences were aligned online using the default gap opening penalty of 1.53 in MAFFT (Multiple Sequence Alignment based on Fast Fourier Transform) ver. 7 (Katoh \& Toh 2008) using the following alignment strategy: Auto (FFT-NS-2, FFTNS-i or L-INS-i, depending on data size). These aligned matrices were subsequently used in analyses.

\section{Molecular analyses, species delimitation and haplotypes networks}

For molecular species delimitation, the following methods were used for analyzing the concatenated CO1 + ITS2 matrix (1109 characters): 1) corrected $p$-distances under neighbor joining (NJ) using MEGA ver. $7.0 ; 2$ ) automatic barcode gap discovery (ABGD) online version (Puillandre et al. 2012) using both uncorrected and K2P distance matrices; 3) general mixed yule coalescent model (GMYC) (Pons et al. 
Table 2. Primers used for each molecular marker for PCR.

\begin{tabular}{llll}
\hline Gene & Primer name & Primer sequence $\left(\mathbf{5}^{\prime}-\mathbf{3}^{\prime}\right)$ & Reference \\
\hline \multirow{4}{*}{ CO1 } & LCO & GGT CAA CAA ATC ATA AAG ATA TTG G & Folmer et al. \\
& HCO & TAA ACT TCA GGG TGA CCA AAA AAT CA & $(1994)$, \\
& LCO-JJ & CHA CWA AYC ATA AAG ATA TYG G & Astrin \& Stueben \\
& HCO-JJ & AWA CTT CVG GRT GCV CAA ARA ATC A & $(2008)$ \\
\hline \multirow{4}{*}{ ITS2 } & \multirow{2}{*}{ 5.8S } & CAC GGG TCG ATG AAG AAC GC & Ji et al. (2003), \\
& CAS28sB1d & TTC TTT TCC TCC SCT TAY TRA TAT GCT TAA & $\begin{array}{l}\text { Planas \& Ribera } \\
(2014)\end{array}$ \\
\hline
\end{tabular}

2006) using GMYC web server (https://species.h-its.org/gmyc/); and 4) Bayesian Poisson tree processes (bPTP) (Zhang et al. 2013; Kapli et al. 2017) using web server (https://species.h-its.org/ptp/).

\section{$P$-distances under neighbor joining (NJ)}

The bootstrap values in the NJ analysis were calculated with the following commands: Number of replicates $=1000$, bootstrap support values $=1000$ (significant values $\geq 50 \%$ ), Substitution type $=$ nucleotide, Model $=$ Kimura 2-parameter, Substitution to Include $=\mathrm{d}$ : Transitions + Transversions, Rates among Sites $=$ Gamma distributed $(\mathrm{G})$, Missing Data Treatment $=$ Pairwise deletion, Select Codon Position $=1^{\text {st }}+2^{\text {nd }}+3^{\text {rd }}+$ Noncoding Sites.

\section{Starting trees under Maximum Likelihood (ML) and Bayesian Inference (BI)}

The approaches for DNA barcoding tree-based delimitation explicitly use the phylogenetic species concept. An input starting tree generated with ML using MEGA ver. 7.0 and BI performed by MrBayes ver. 3.1.2 (Ronquist \& Huelsenbeck 2003) were implemented, and the analysis recognized monophyletic clusters by searching differential intra- and interspecific branching patterns (Ortiz \& Francke 2016). The ML analysis was calculated with the parameters for COI and ITS2: Number of replicates $=1000$, bootstrap support values $=1000$ (significant values $\geq 50 \%$ ), Models of sequence evolution selected using jModelTest $=$ GTR, Rates among sites $=\mathrm{G}+\mathrm{I}$, No. of discrete Gamma Categories $=6$, Gaps Data Treatment $=$ Complete deletion, Select Codon Position $=1^{\text {st }}+2^{\text {nd }}+3^{\text {rd }}+$ Noncoding Sites, ML Heuristic Method $=$ Subtree-Pruning-Regrafting - Extensive (SPR level 5), Initial Tree for ML $=$ Make initial tree automatically (Default - NJ/BioNJ). The BI analyses were run with four parallel Markov chains with the following parameters: MCMC (Markov Chain Monte Carlo) generations $=20000000$, sampling frequency $=1000$, print frequency $=1000$, number of runs $=2$, number of chains $=4$, MCMC burnin $=2500$, sumt burn-in $=2500$, sump burn-in $=2500$, Models of sequence evolution selected using $\mathrm{j}$ ModelTest $=$ GTR, Rates among sites $=\mathrm{G}+\mathrm{I}$, Select Codon Position $=11^{\text {st }}, 2^{\text {nd }}$ and $3^{\text {rd }}$. TRACER ver. 1.6 (Rambaut \& Drummond 2014) was used to analyze the parameters and the effective sample size (ESS) of the MCMC to ensure the runs converged. FigTree ver. 1.4.3 was used to visualize the topology of the tree with the posterior probability values (PP) at nodes. The models of sequence evolution were selected using the Akaike information criterion (AIC) in jModelTest ver. 2.1.10 (Posada \& Buckley 2004). The models selected for $\mathrm{CO} 1$ and ITS 2 for each partition block were: $\mathrm{GTR}+\mathrm{G}+\mathrm{I}\left(1^{\text {st }}\right.$ and $2^{\text {nd }}$ codon positions $)$ and GTR $+\mathrm{G}$ ( $3^{\text {rd }}$ position). The model selected for ITS2 was GTR $+\mathrm{G}$.

\section{Automatic barcode gap discovery (ABGD)}

The ABGD species delimitation method uses recursive partitioning with a range of prior intraspecific divergence and relative gap widths, estimating the threshold between intra- and interspecific genetic variation, generating species-level groupings (Ortiz \& Francke 2016). ABGD analyses were conducted using both uncorrected and K2P distance matrices with default options: Pmin $=0.001$, Pmax $=0.1$, Steps $=10$, Relative gap width $(\mathrm{X})=1, \mathrm{Nb}$ bins $=20$. 


\title{
General mixed yule coalescent model (GMYC)
}

The GMYC species delimitation method applies single (Pons et al. 2006) or multiple (Monaghan et al. 2009) time thresholds to delimit species in a Maximum Likelihood context, using ultrametric trees (Ortiz \& Francke 2016). Phylogenetic analyses were run in BEAST ver. 2.6.0 (Drummond et al. 2012) using a coalescent (constant population) tree prior. Independent lognormal relaxed clock was applied to each partition, for analyses $20 \times 10^{6}$ generations were run. Convergence was assessed with TRACER ver. 1.6 (Rambaut \& Drummond 2014). TREEANNOTATOR ver. 2.6.0 (BEAST package) was used to build maximum clade credibility trees, after discarding the first $25 \%$ of generations by burn-in. Following gene tree inference, GMYC was implemented in the web interface for single and multiple threshold GMYC (https://species.h-its.org/gmyc/). The backend of this web server runs the original R implementation of the GMYC model authored by Fujisawa \& Barraclough (2013). A single threshold was used for the concatenated matrix.

\section{Bayesian Poisson tree processes (bPTP)}

The PTP species delimitation method (Zhang et al. 2013) is similar to GMYC, but uses substitution calibrated (not ultrametric) trees to avoid the potential flaws in constructing time calibrated phylogenies (Zhang et al. 2013; Ortiz \& Francke 2016). We employed the Bayesian variant of the method (bPTP) on the online version (https://species.h-its.org/ptp/). It was run on the Bayesian gene trees with default options: rooted tree, MCMC generations $=100000$, Thinning $=100$, Burn-in $=0.1$, Seed $=123$. Haplotypes network for $\mathrm{COl}$ was constructed to visualize the mutations among haplotypes of species using the TCS algorithm (Clement et al. 2000) in PopArt ver. 1.7 (Leigh \& Bryant 2015). The trees generated were edited using Adobe Photoshop CS6.

\section{Results}

\author{
Phylum Arthropoda von Siebold, 1848 \\ Class Arachnida Cuvier, 1812 \\ Order Araneae Clerck, 1757 \\ Family Sicariidae Keyserling, 1880
}

Genus Loxosceles Heineken \& Lowe, 1832

Type species: Loxosceles citigrada Heineken \& Lowe, 1832 (= Scytodes rufescens Dufour, 1820), currently Loxosceles rufescens (Dufour, 1820).

\section{Loxosceles tolantongo sp. nov. urn:lsid:zoobank.org:act:C49E731B-3592-4AF2-8C3B-7DA78E4E2D47}

Figs 1-9, 16-33, 36-39

\section{Differential diagnosis}

Loxosceles tolantongo sp. nov. morphologically resembles L. jaca Gertsch \& Ennik, 1983, also from Hidalgo. However, in lateral view, the palp tibia of the male L. tolantongo sp. nov. is slightly longer than in $L$. jaca and the curvature of the basal-ventral part of the tibia is less pronounced than in L. jaca (Figs 20, 22, 30, 33), where it is prominent and totally curved (Figs 34-35, 44, 46). In dorsal view, the palp tibia of $L$. tolantongo sp. nov. is thinner and longer (Fig. 21), whereas in L. jaca it is wider and shorter (Fig. 45). In the new species, in lateral view, the embolus is slightly wider basally than that of L. jaca (Figs 20, 22 vs Figs 44, 46). In lateral and dorsal views, the tip of the embolus in L. tolantongo sp. nov. is slightly curved (Figs 20, 22, 24), whereas in L. jaca it is sigmoid (Figs 44, 46, 48). The seminal receptacles of the females of both species are similarly S-shaped (Figs 36-39, 40-43). However, the shape of the base of the receptacles is different: in L. tolantongo sp. nov. it is oval-shaped (Figs 28, 36-39), whereas in L. jaca it is square-shaped (Figs 40-43). Also, the base of seminal receptacles is more sclerotized in L. tolantongo sp. nov. than in L. jaca (Figs 28, 36-39, 40-43). 


\section{Etymology}

The species name is a noun in apposition and refers to the type locality of the new species: the Tourist Center Grutas de Tolantongo, located in the Mezquital Valley, Hidalgo, Mexico.

\section{Material examined}

\section{Holotype}

MEXICO - Hidalgo • $\overbrace{}^{\top}$; Municipality of Cardonal, Tourist Center Grutas de Tolantongo; $20.6503^{\circ} \mathrm{N}$, 99.0047 W; 1315 m a.s.1.; 17 Mar. 2017; A. Valdez, E. Briones, J. Valerdi, A. Juárez and M. Sánchez leg.; night collecting; CNAN-T01317.

\section{Paratypes}

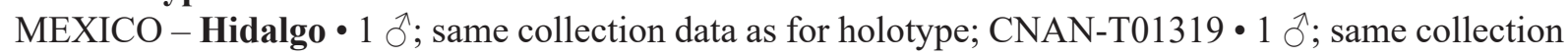
data as for holotype; 22 May 2018; A. Valdez, J. Valerdi, A. Cabrera, P. Solís and I. Navarro leg.; diurnal collecting; CNAN-T01320 • 2 우; same collection data as for preceding; CNAN-T01321, CNAN-T01324 1 त ; Municipality of Cardonal, Tourist Center Grutas de Tolantongo, $500 \mathrm{~m}$ west of entrance No. 5; $20.6446^{\circ} \mathrm{N}, 98.9973^{\circ} \mathrm{W} ; 1481$ m a.s.l.; 22 May 2018; A. Valdez, J. Valerdi, A. Cabrera,
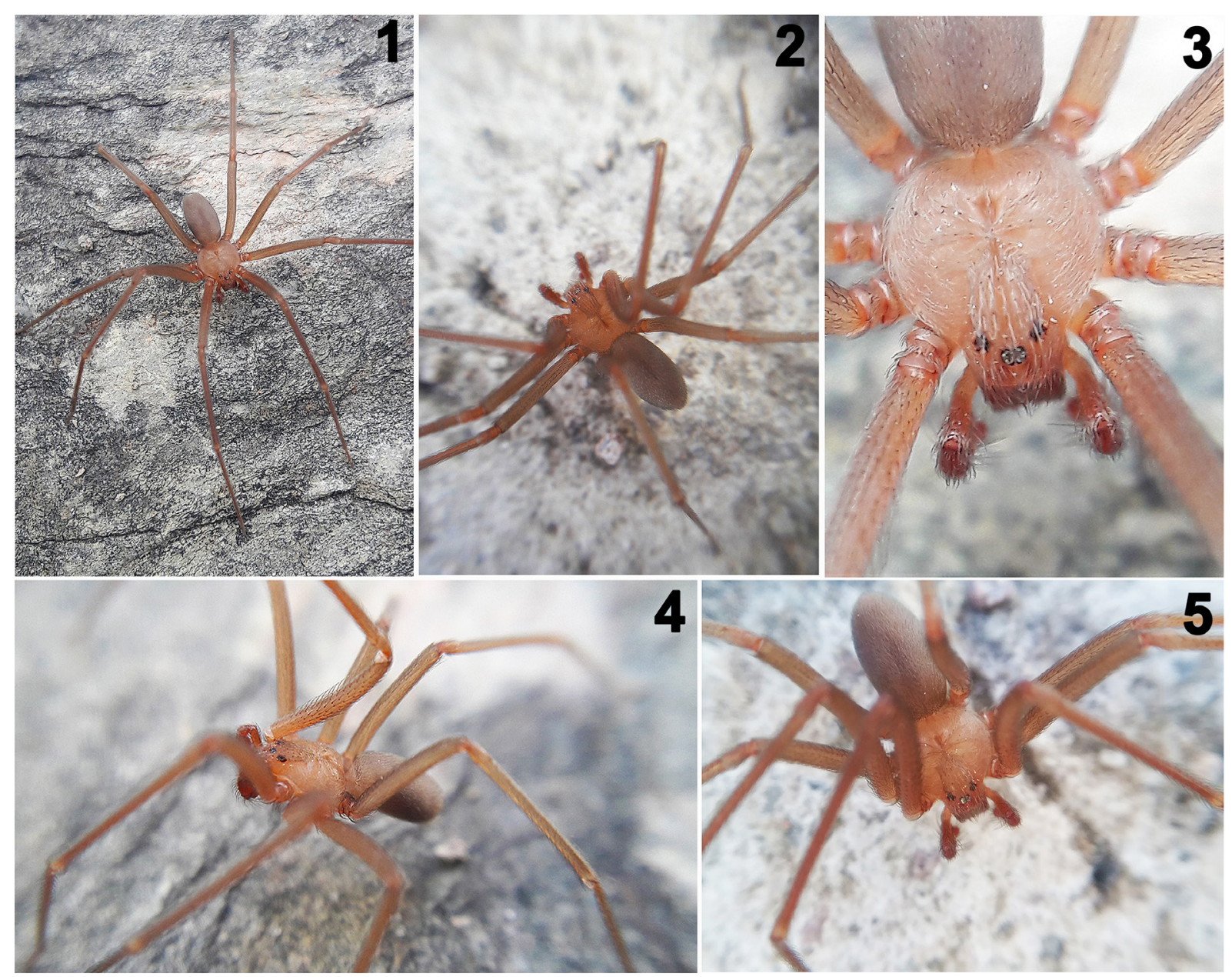

Figs 1-5. Live male holotype (CNAN-T01317) of Loxosceles tolantongo sp. nov. from the type locality: Tourist Center Grutas de Tolantongo, Municipality of Cardonal, Hidalgo, Mexico. Photos 1-4 by Alejandro Valdez-Mondragón (2019); photo 5 by Claudia Isabel Navarro-Rodríguez (2019). 
P. Solís and I. Navarro leg.; diurnal collecting; CNAN-T01318 • 2 q $q$; same collection data as for preceding; CNAN-T01322, CNAN-T01323.

\section{Other material}

MEXICO - Hidalgo • 1 ๙, 5 immatures; Municipality of Cardonal, Tourist Center Grutas de Tolantongo, $500 \mathrm{~m}$ west of entrance No. 5; 20.6446 ${ }^{\circ} \mathrm{N}, 98.9973^{\circ} \mathrm{W} ; 1481 \mathrm{~m}$ a.s.1.; 22 May 2018; A. Valdez, J. Valerdi, A. Cabrera, P. Solís and I. Navarro leg.; diurnal collecting; LATLAX Ara-0488 • 1 ภ, 1 immature; same collection data as for holotype; 23 May 2018; LATLAX Ara-0490 • 2 immatures; same collection data as for holotype; 22 May 2018; A. Valdez, J. Valerdi, A. Cabrera, P. Solís and I. Navarro leg.; diurnal collecting; LATLAX Ara-0489 • 1 $\delta, 2$ immatures; same collection data as for holotype; LATLAX Ara0137 • 6 우, 4 immatures; Municipality of Cardonal, Tourist Center Grutas de Tolantongo, 'El Paraiso' trail; 20.6502 N, $99.0002^{\circ}$ W; 1312 m a.s.1.; 24 Jan. 2019; A. Valdez, P. Solís, M. Cortez, J. Sánchez and D. Montiel leg.; LATLAX Ara-0527, Ara-0528.

\section{Description}

Male (holotype CNAN-T01317)

Specimen collected manually, preserved and observed in $80 \%$ ethanol.

Measurements. Total length 5.60. Carapace: 2.60 long, 2.30 wide. Clypeus length 0.25. Diameter of AME 0.20, PME 0.17, PLE 0.13; AME-PME 0.11. Labium: length 0.44, width 0.50. Sternum: length 1.40, width 1.25. Leg lengths: I (total 14.80): femur 4.0/patella $0.9 /$ tibia $4.6 /$ metatarsus $4.1 /$ tarsus 1.2; II (15.20): 4.4/0.7/4.6/4.4/1.1; III (12): 3.6/0.6/3.2/3.6/1; IV (14.60): 4/0.7/3.7/4.9/1.3. Leg formula: 2-1-4-3.
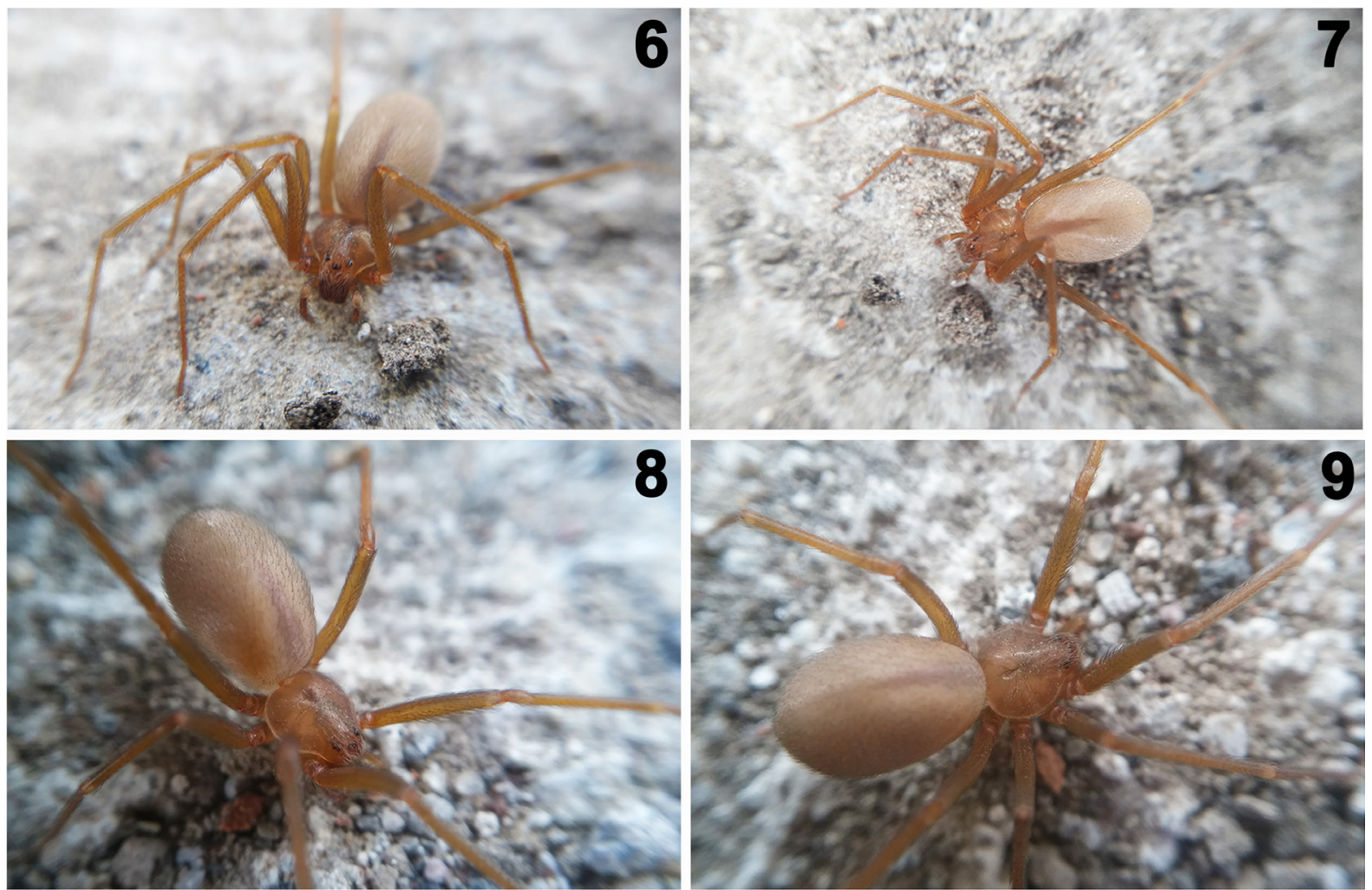

Figs 6-9. Live female paratype (CNAN-T01321) of Loxosceles tolantongo sp. nov. from the type locality: Tourist Center Grutas de Tolantongo Municipality of Cardonal, Hidalgo, Mexico. Photos 6-7 by Alejandro Valdez-Mondragón (2019); photos 8-9 by Claudia Isabel Navarro-Rodríguez (2019). 

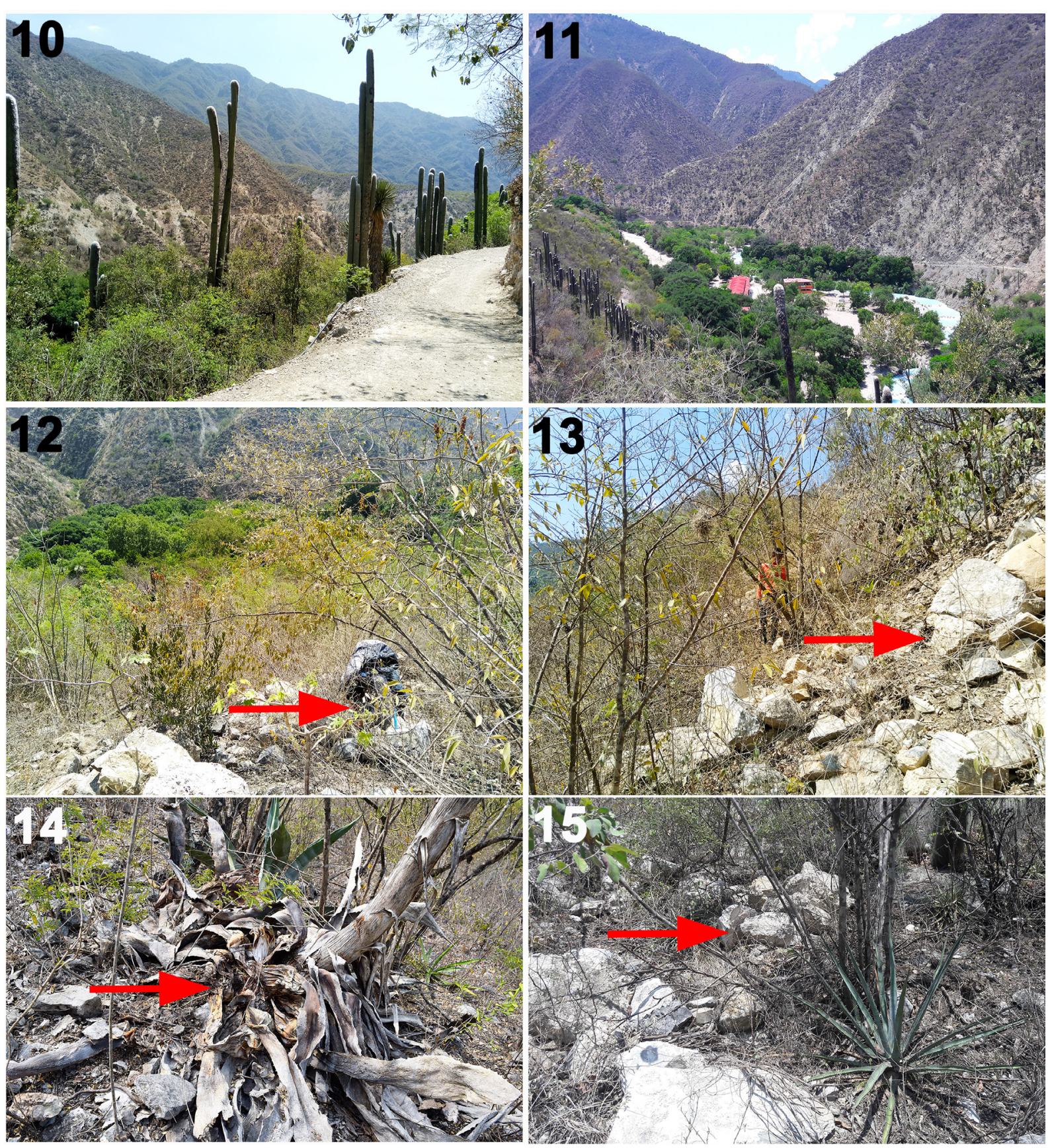

Figs 10-15. Habitat and microhabitat of Loxosceles tolantongo sp. nov. 10-11. Xerophytic forest from the type locality: Tourist Center Grutas de Tolantongo, Municipality of Cardonal, Hidalgo, Mexico. 12-15. Microhabitat situated $500 \mathrm{~m}$ west of entrance No. 5 to the Tourist Center Grutas de Tolantongo, Municipality of Cardonal, Hidalgo, Mexico (arrows indicate the microhabitat where the specimens can be found: under big rocks and inside of rotten and dry agave plants). Photos 10, 12-14 by Claudia Isabel Navarro-Rodríguez (2018); photos 11, 15 by Alejandro Valdez-Mondragón (2018). 
Prosoma. Carapace reddish, longer than wide, pyriform, dorsally with slightly dark brown 'violin' pattern (Figs 1-5, 16, 26), which is darker brown than rest of body (Figs 1-5, 16, 26). Carapace without lateral spots like other species. Six eyes in three groups, clypeus reddish brown (Figs 1-5, 16, 26). Sternum pale reddish, longer than wide (Fig. 17). Labium reddish brown, wider than long, fused to the sternum (Fig.17). Endites pale brown basally, reddish brown distally and white apically. Endites longer than wide, rounded basally (Fig.17).

LeGs. Coxae, trochanters, femora and patella reddish brown, paler on femora III and IV (Figs 1-5, 16-17), and the rest of the leg browner (Figs 1-5, 16).

Chelicerae. Fused basally, reddish brown, stridulatory lines laterally. Fangs reddish brown, with thin setae around them (Fig. 17).

Opisthosoma. Dark gray, paler posteriorly (Fig 1-5, 16), oval, longer than wide, and high (Figs 1-5, 16-17). Region of gonopore pale gray, with small setae. Colulus reddish brown, conical (Fig. 17). Spinnerets reddish brown, cylindrical; anterior lateral spinnerets longest, posterior median spinnerets smallest, with long setae. Tracheae opening near posterior margin of opisthosoma.
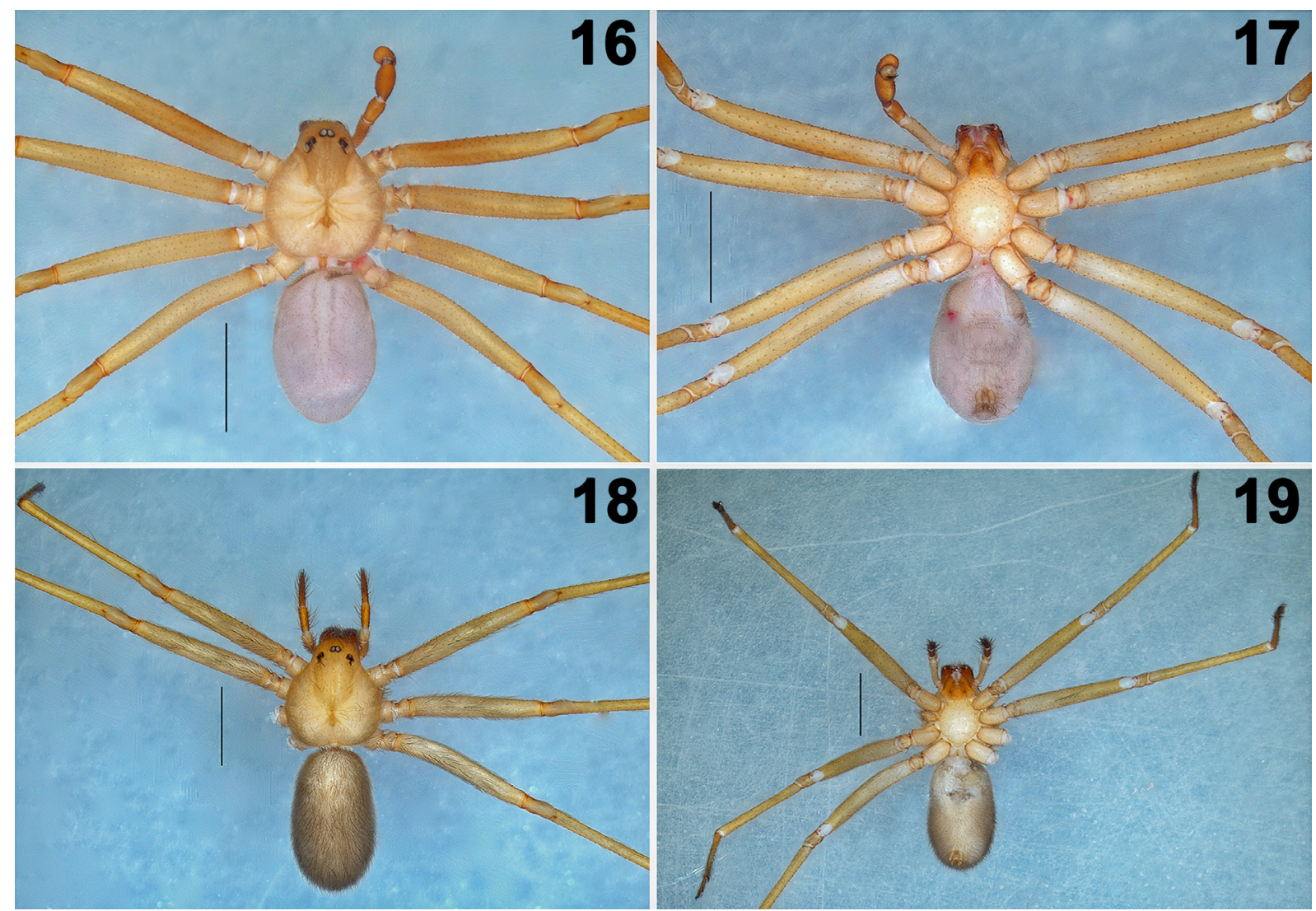

Figs 16-19. Loxosceles tolantongo sp. nov. 16-17. Habitus of $\widehat{\jmath}$ holotype (CNAN-T01317), dorsal and ventral views, respectively. 18-19. Habitus of $q$ paratype (CNAN-T01321), dorsal and ventral views, respectively. Scale bars $=2 \mathrm{~mm}$. 
PALPS. Trochanters and femora pale reddish, paler ventrally in femora; patellae, tibiae reddish brown, longer than wide, wider in distal half than basal half (Figs 20, 22, 30-33). Tarsus oval, reddish brown, bulb spherical, embolus short, thick at base, narrowed to fine point (Figs 20-25).

Female (paratype CNAN-T01264)

Specimen collected manually, preserved and observed in $80 \%$ ethanol.

Measurements. Total length 6.64. Carapace: 2.71 long, 2.56 wide. Clypeus length 0.34. Diameter of AME 2, PME 1.8, PLE 1.8; AME-PME 0.2. Labium: length 0.42, width 0.57. Sternum: length 1.56, width 1.36. Leg lengths: I (total 12.42): femur 3.6/patella $0.88 /$ tibia $3.36 /$ metatarsus 3.40/tarsus 1.18; II (16.65): 3.8/1.0/3.8/3.45/4.6; III (11.72): 3.60/ 0.96/3.04/3.06/1.06; IV (13.23): 3.44/0.96/3.52/4.0/1.31. Leg formula: 2-4-1-3.
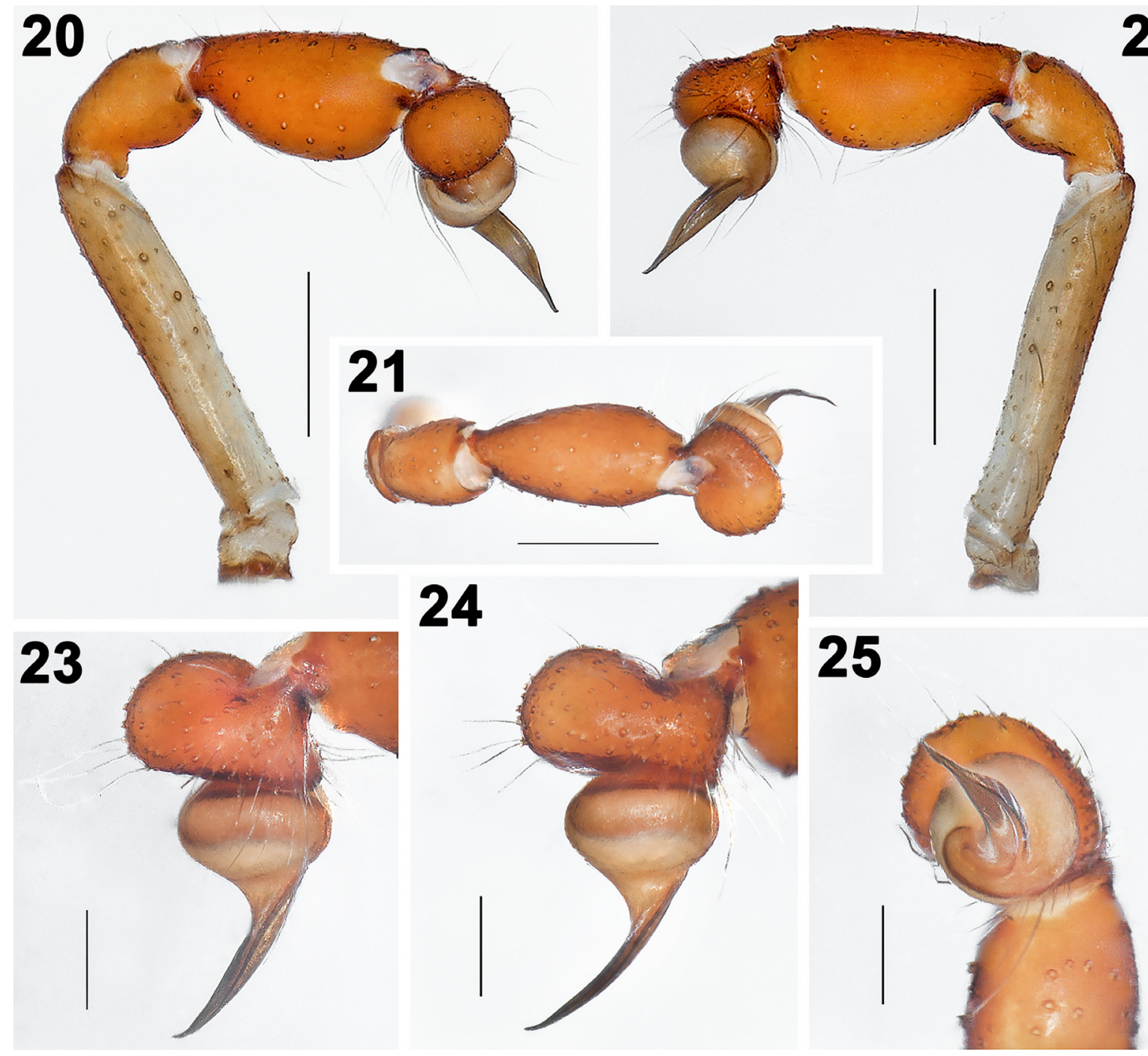

Figs 20-25. Loxosceles tolantongo sp. nov., ô holotype (CNAN-T01317). 20-22. Left palp, prolateral, dorsal and retrolateral views, respectively. 23-25. Detail of the bulb and embolus, retrolateral, dorsal and apical views, respectively. Scale bars: $20-22=0.5 \mathrm{~mm} ; 23-25=0.2 \mathrm{~mm}$. 
Differs from male as follows:

Prosoma. Carapace brown and pale brown, with less defined dark brown 'violin' pattern (Figs 6-9, 18, 27). Larger carapace. Sternum paler brown (Fig. 19). Labium more reddish brown. Endites more reddish brown.

LeGs. Coxae, trochanters, femora, patella and tibiae brown (Figs 6-9, 18-19). Metatarsi and tarsi dark brown (Figs 6-9, 18-19).

Chelicerae. Darker reddish brown.

Opisthosoma. Brown and pale brown (Figs 6-9, 18-19). Spinnerets paler brown.

PALPs. Trochanters, femora and patellae pale brown, tibiae and tarsi reddish brown. Tibiae cylindrical, tarsi conical (Figs 18-19).

Genital area. Seminal receptacles asymmetric, S-shaped (Fig. 28). Base of seminal receptacles oval and wide, sclerotized (Fig. 28). See variation section for more details (Figs 36-39).

\section{Variation}

\section{Males}

Males collected from the Tourist Center Grutas de Tolantongo and from $500 \mathrm{~m}$ west of entrance No. 5 are pale brown, with legs the same color as carapace; in some cases the legs are darker than the body. The male holotype is darker brown that all other specimens. The male collected from 'El Paraiso' trail is dark
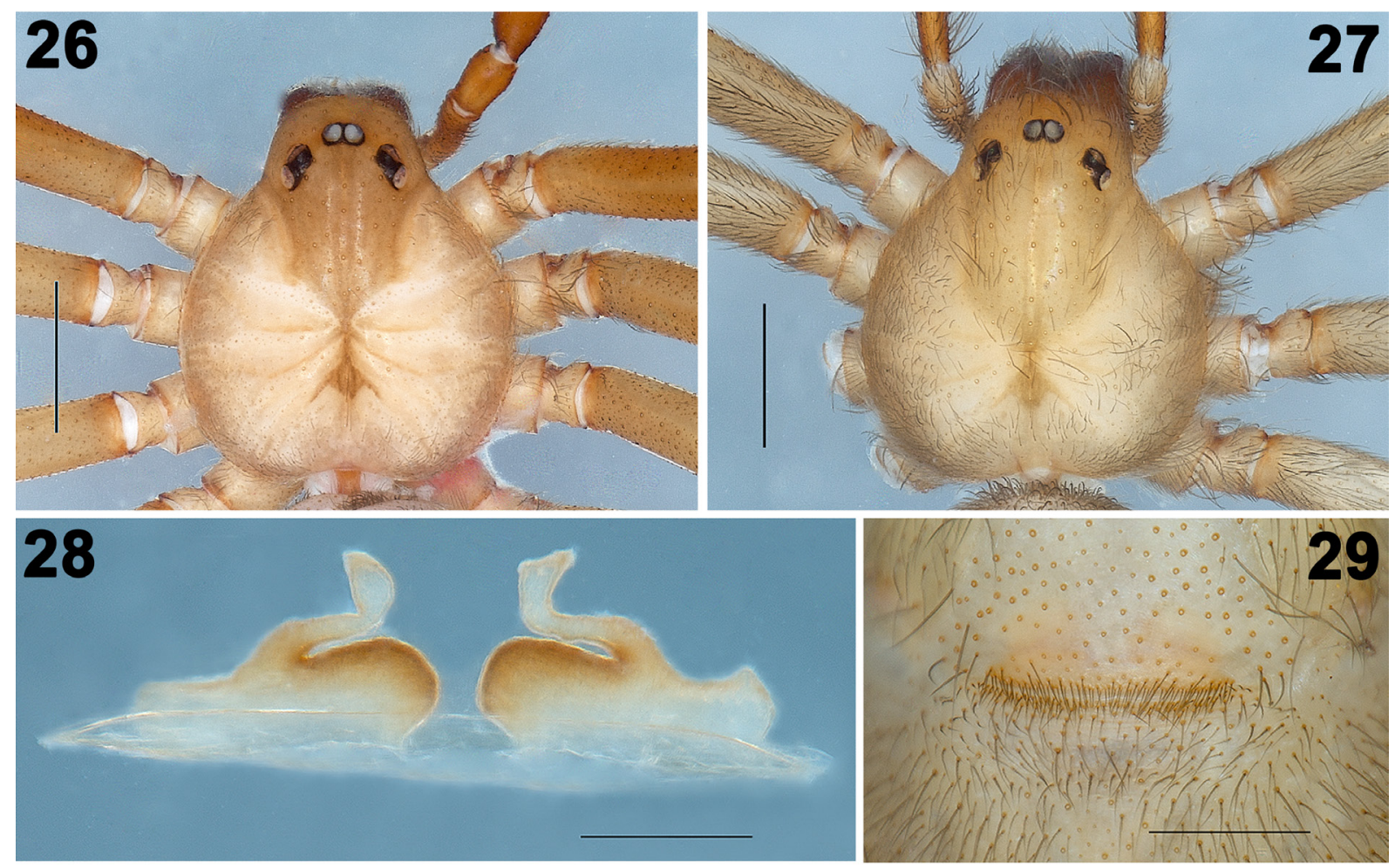

Figs 26-29. Loxosceles tolantongo sp. nov. 26-27. Caparace of $\widehat{\delta}$ holotype (CNAN-T01317) and $q$ paratype (CNAN-T01321), respectively. 28-29. + paratype (CNAN-T01321). 28. Seminal receptacles. 29. Genital area, ventral view. Scale bars: $26-27=1 \mathrm{~mm} ; 28=0.2 \mathrm{~mm} ; 29=0.5 \mathrm{~mm}$. 

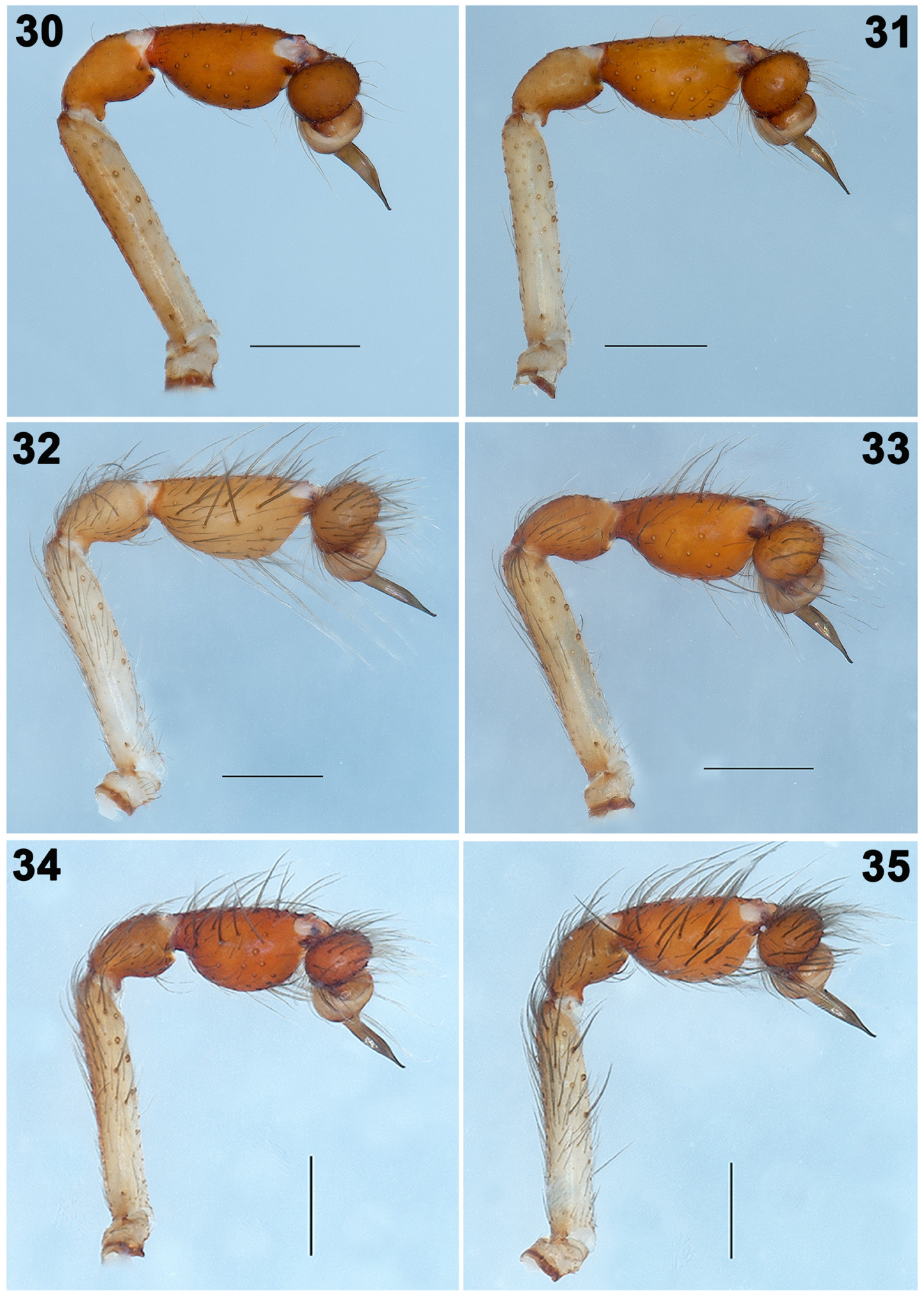

Figs 30-35. Variation of the male palps, left palps, prolateral views. 30-33. Loxosceles tolantongo sp. nov. 30-32. Tourist Center Grutas de Tolantongo, Municipality of Cardonal, Hidalgo (type locality). 33. $500 \mathrm{~m}$ west of the entrance No. 5 to the Tourist Center Grutas de Tolantongo, Municipality of Cardonal, Hidalgo. 34-35. Loxosceles jaca Gertsch \& Ennik, 1983. $2.5 \mathrm{~km}$ north of Jacala de Ledezma, Municipality of Jacala de Ledezma, Hidalgo. Scale bars $=0.5 \mathrm{~mm}$. 
reddish brown, with legs the same color as body. Tourist Center Grutas de Tolantongo, Municipality of Cardonal $(N=5)$ : Tibia I 4.1-5.4 $(x=5)$; carapace length $(\mathrm{CL}) 2.2-2.6(x=2.5)$, carapace width $(\mathrm{CW})$ 2.1-2.3 $(x=2) .500 \mathrm{~m}$ west of entrance No. 5, Municipality of Cardonal $(N=2)$ : Tibia I 4.1-4.3 $(x=$ 4), CL 2.2-2.4 ( $x=2)$, CW 2.0-2.2 $(x=2)$. 'El Paraiso' trail, Municipality of Cardonal $(N=1)$ : Tibia I 5.2, CL 2.7, CW 2.4.

The male palps present a little variation. In the case of the holotype the palp has more marked coloration and the embolus is wider at the base (Figs 20-25, 30-33).
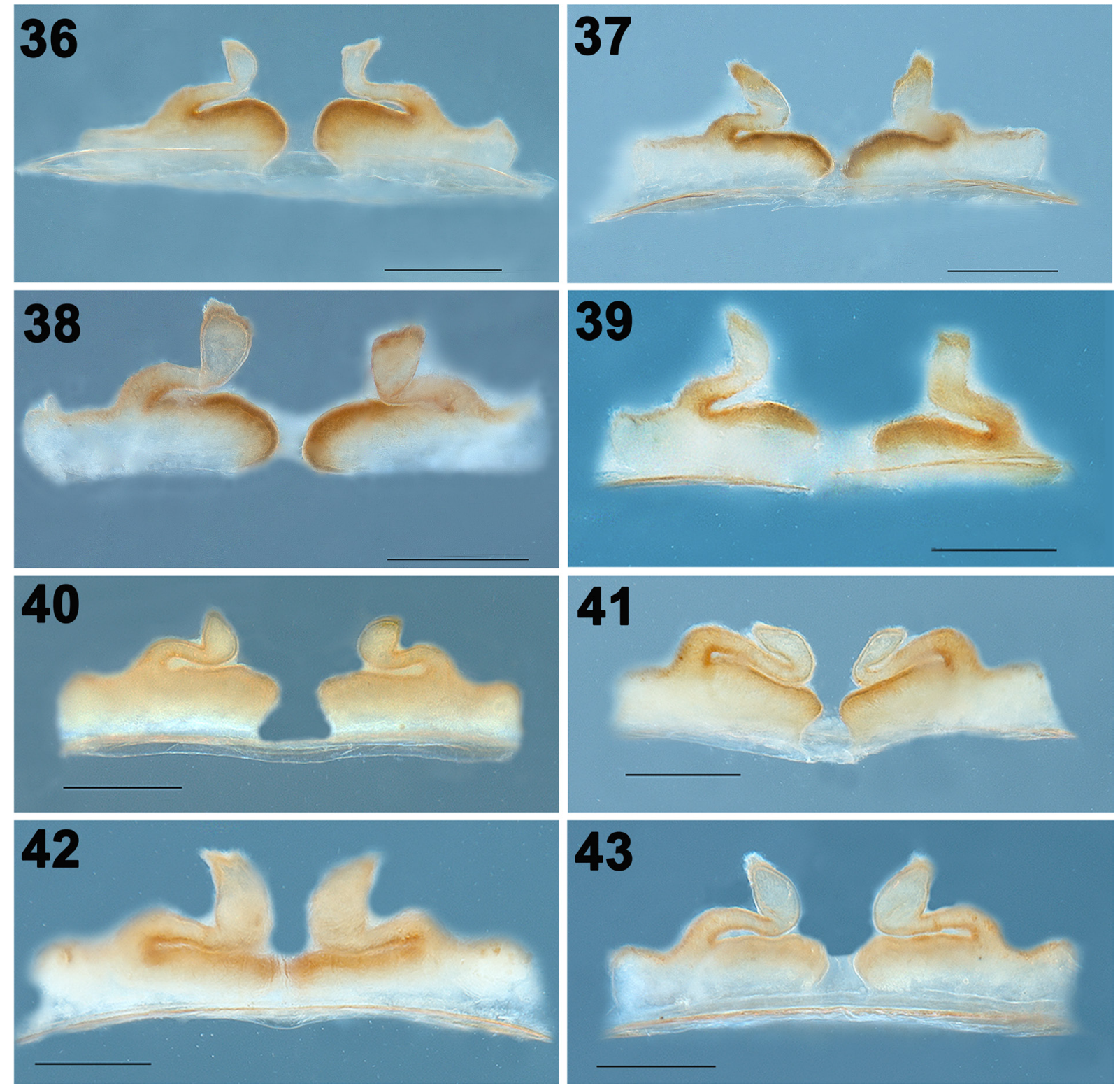

Figs 36-43. Variation of the seminal receptacles of females, dorsal view. 36-39. Loxosceles tolantongo sp. nov. 36, 39. Tourist Center Grutas de Tolantongo, Municipality of Cardonal. 37-38. $500 \mathrm{~m}$ west of the entrance No. 5 to the Tourist Center Grutas de Tolantongo, Municipality of Cardonal. 40-43. Loxosceles jaca Gertsch \& Ennik, 1983. $2.5 \mathrm{~km}$ north of Jacala de Ledezma, Municipality of Jacala de Ledezma, Hidalgo. Scale bars $=0.2 \mathrm{~mm}$. 


\section{Females}

The female collected from the Tourist Center Grutas de Tolantongo is pale brown on carapace and legs. Females from $500 \mathrm{~m}$ west of entrance No. 5 are dark brown on carapace and legs. Females from 'El Paraiso' trail are dark brown on carapace, with light brown legs. Tourist Center Grutas de Tolantongo, Municipality of Cardonal $(N=2)$ : Tibia I 3.3-3.3 $(x=3)$, CL 2.2-2.7 $(x=3)$, CW 2.0-2.5 $(x=2) .500 \mathrm{~m}$ west of entrance No. 5, Municipality of Cardonal $(N=2)$ : Tibia I missing-3.2, CL 2.6-2.6 $(x=3)$, CW 2.2-2.3 (x=2). 'El Paraiso' trail, Municipality of Cardonal $(N=6)$ : Tibia I 3.1-3.9 $(x=3)$, CL 2.4-2.7 $(x=3)$, CW 2.2-2.4 (x=2).

The seminal receptacles of females are S-shaped, asymmetrical and broadly variable in shape, even in specimens from the same locality (Figs 36-39). The apical lobes are rounded in some specimens, oval in
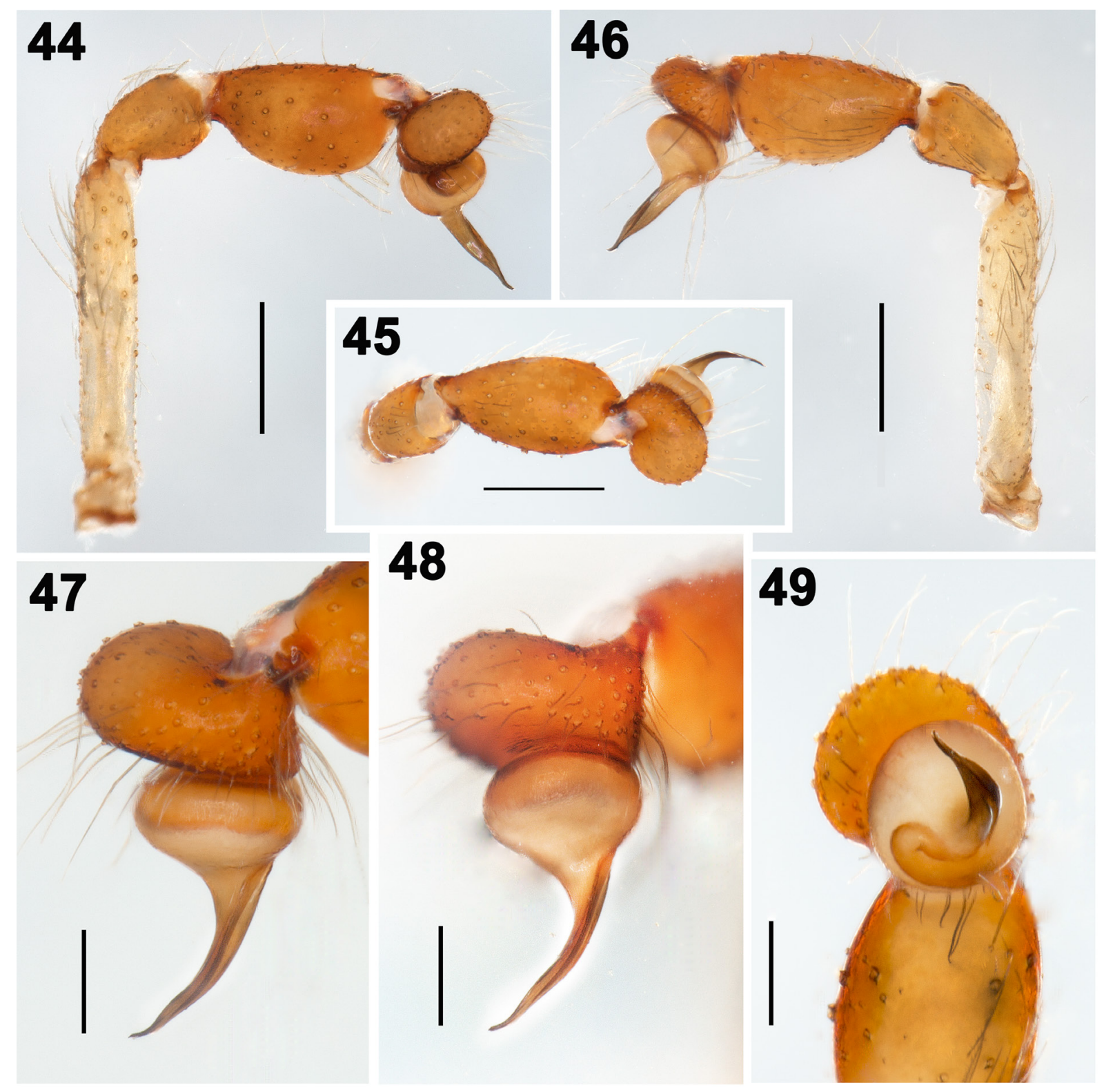

Figs 44-49. Loxosceles jaca Gertsch \& Ennik, 1983. 44-46. Left palp, prolateral, dorsal and retrolateral views respectively. 47-49. Detail of the bulb and the embolus: retrolateral, dorsal and apical views, respectively. Scale bars: $44-46=0.5 \mathrm{~mm} ; 47-49=0.2 \mathrm{~mm}$. 
others, or even with a sharp tip (Figs 28, 36-39). The base of the seminal receptacles is variable, in some specimens it is wider, more rounded and more sclerotized than in others (Figs 28, 36-39).

\section{Natural history}

The specimens of $L$. tolantongo sp. nov. were collected in a xerophytic forest, the native vegetation type around the Touristic Center Grutas de Tolantongo (Figs 10-15). The microhabitat where the specimens were collected was under big rocks, and from inside rotten and dry agave plants (Figs 12-15). Some specimens were collected close to each other.

\section{Distribution}

MEXICO: Hidalgo (Figs 50-51).

\section{Molecular analyses and species delimitation}

The analyzed matrices include 49 individuals of ten species of Loxosceles, 38 individuals for the CO1 data set and 42 individuals for ITS2 (Table 1, Figs 52-56). Specimens used in this study, GenBank accession numbers and localities of the specimens are listed in Table 1. The average genetic $p$-distance among analyzed species was $15.9 \%$ for $C O 1$ and $8.4 \%$ for ITS2 (Figs 52-53). Corrected $p$-distances from the CO1 and ITS2 data recovered nine species of Loxosceles, both with high bootstrap support values (Figs 52-53). Based on the genetic analyses, L. tolantongo sp. nov. is closely related to $L$. jaca + L. tenango with CO1 (Fig. 52), and with L.jaca with ITS2 (Fig. 53); with an average $p$-distance between $L$. tenango and $L$. tolantongo sp. nov. of $9.6 \%$, and between $L$. jaca and $L$. tolantongo sp. nov. of $10.5 \%$ for $C O 1$ and $1.8 \%$ for ITS2 (Tables 3-4). Molecular analyses with CO1 and the concatenated matrix $(C O 1+I T S 2)($ Figs 54, 56) indicate that four different species delimitation methods, including the morphology, were congruent to delimit $L$. tolantongo sp. nov. as a valid and different species, and recovered a total of nine species. However, using the ABGD species delimitation method under recursive partitions (RP), 14, 11 and 10 species were recovered (Fig. 54). The molecular analyses are consistent with the morphology; the nine species of Loxosceles used in this study were previously described only with morphological characters, except for L. tenochtitlan which was described with different lines of evidence (morphological and molecular) by Valdez-Mondragón et al. (2019). Molecular analyses with ITS2 indicate that of the four different molecular species delimitation methods, only NJ and GMYC (Yule) were consistent with the morphology for delimitation of $L$. tolantongo sp. nov. (Figs 53, 55). ABGD and bPTP species delimitation methods do not recover L. totaltongo as a different species, but they recover other species, such as L. zapoteca Gertsch, 1958, L. colima Gertsch, 1958 (except with initial partitions (IP) (ABGD)) and L. malintzi (Fig. 55). The haplotype network analysis with CO1 data is concordant with the results of the different species delimitation analyses (Fig. 57). There were $>10$ mutations between haplotypes under COI for all the species (Fig. 57). Regarding L. tolantongo sp. nov. and $L$. jaca $+L$. tenango, the haplotype network was concordant with the species delimitation, and showed a total of 39 and 36 mutations respectively between haplotypes under CO1 (Fig. 57).

\section{Discussion}

There are currently two important tasks to which DNA barcodes markers are being applied in modern systematics. The first is distinguishing between species (equivalent to species identification or species diagnosis) and the second is the use of DNA data to discover new species (equivalent to species delimitation and species description) (DeSalle et al. 2005). For some groups of organisms, such as spiders, traditional morphology in some cases fails to determine species boundaries, and identifying morphologically inseparable cryptic or sibling species requires a new set of taxonomic tools, including the analysis of molecular data (Jarman \& Elliott 2000; Witt \& Hebert 2000; Proudlove \& Wood 2003; Hebert et al. 2003, 2004; Bickford et al. 2007; Hamilton et al. 2011, 2014, 2016; Ortiz \& Francke 2016; Valdez-Mondragón et al. 2019). 


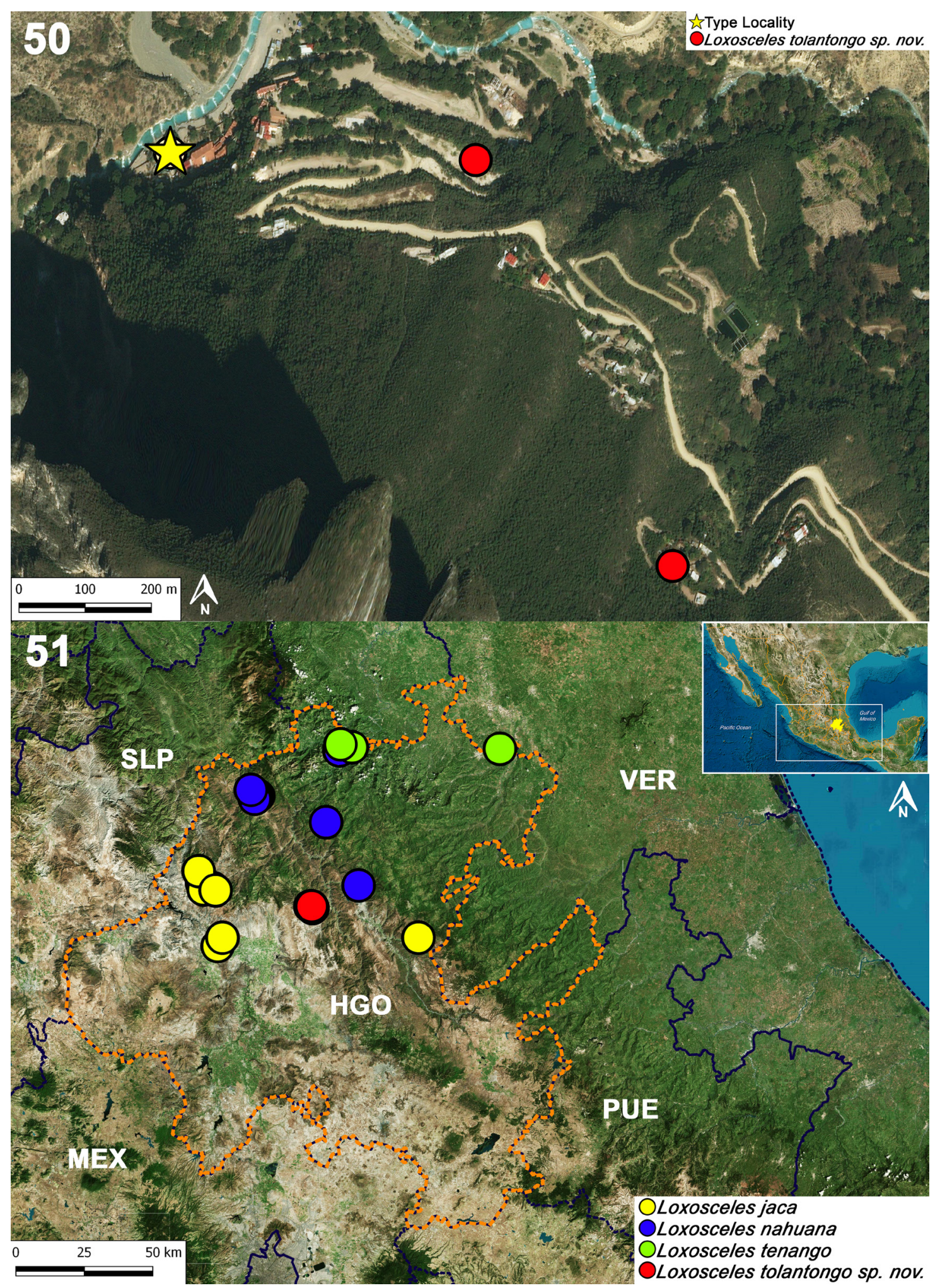

Figs. 50-51. Distribution records of Loxosceles tolantongo sp. nov. from Hidalgo. 50. Known records of Loxosceles tolantongo sp. nov. from the Tourist Center Grutas de Tolantongo, Municipality of Cardonal, Hidalgo, including the type locality. 51. Distribution records of the four species of Loxosceles from Hidalgo, Mexico. Abbreviations: $\mathrm{HGO}=$ Hidalgo; $\mathrm{MEX}=$ Estado de Mexico; PUE $=$ Puebla; SLP $=$ San Luis Potosí; VER = Veracruz. 
Table 3. Genetic $p$-distance matrix from the CO1 data among Loxosceles tolantongo sp. nov., L. tenango Gertsch, 1973 and L. jaca Gertsch \& Ennik, 1983. Average $p$-distance $=6.7 \%$.

\begin{tabular}{llllllllll}
\hline Species & $\mathbf{1}$ & $\mathbf{2}$ & $\mathbf{3}$ & $\mathbf{4}$ & $\mathbf{5}$ & $\mathbf{6}$ & $\mathbf{7}$ & $\mathbf{8}$ & $\mathbf{9}$ \\
\hline 1. Ara0191 - L. tenango & & & & & & & & & \\
2. Ara0192 - L. tenango & 0.000 & & & & & & & & \\
3. Ara0186 - L. jaca & 0.071 & 0.068 & & & & & & & \\
4. Ara0048 - L. jaca & 0.073 & 0.070 & 0.002 & & & & & & \\
5. Ara0046 - L. jaca & 0.070 & 0.070 & 0.002 & 0.004 & & & & & \\
6. Ara0047 - L. jaca & 0.067 & 0.068 & 0.002 & 0.004 & 0.005 & & & & \\
7. Ara0183 - L. jaca & 0.085 & 0.085 & 0.017 & 0.018 & 0.018 & 0.020 & & & \\
8. Ara0175 - L. tolantongo sp. nov. & 0.095 & 0.094 & 0.102 & 0.105 & 0.104 & 0.102 & 0.118 & & \\
9. Ara0181 - L. tolantongo sp. nov. & 0.096 & 0.098 & 0.098 & 0.101 & 0.104 & 0.100 & 0.123 & 0.008 & \\
10. Ara0182 - L. tolantongo sp. nov. & 0.094 & 0.097 & 0.097 & 0.100 & 0.103 & 0.099 & 0.123 & 0.010 & 0.005 \\
\hline
\end{tabular}

Table 4. Genetic $p$-distance matrix from the ITS2 data between Loxosceles tolantongo sp. nov. and L. jaca Gertsch \& Ennik, 1983. Average $p$-distance $=1.8 \%$.

\begin{tabular}{lllllllllll}
\hline Species & $\mathbf{1}$ & $\mathbf{2}$ & $\mathbf{3}$ & $\mathbf{4}$ & $\mathbf{5}$ & $\mathbf{6}$ & $\mathbf{7}$ & $\mathbf{8}$ & $\mathbf{9}$ & $\mathbf{1 0}$ \\
\hline 1. Ara0046 - L. jaca & & & & & & & & & & \\
2. Ara0047 - L. jaca & 0.003 & & & & & & & & & \\
3. Ara0186 - L. jaca & 0.021 & 0.018 & & & & & & & & \\
4. Ara0183 - L. jaca & 0.006 & 0.003 & 0.015 & & & & & & & \\
5. Ara0174 - L. tolantongo sp. nov. & 0.016 & 0.013 & 0.020 & 0.015 & & & & & & \\
6. Ara0176 - L. tolantongo sp. nov. & 0.015 & 0.012 & 0.019 & 0.015 & 0.006 & & & & & \\
7. Ara0177 - L. tolantongo sp. nov. & 0.019 & 0.015 & 0.023 & 0.018 & 0.009 & 0.009 & & & & \\
8. Ara0178 - L. tolantongo sp. nov. & 0.021 & 0.018 & 0.025 & 0.020 & 0.012 & 0.006 & 0.015 & & & \\
9. Ara0181 - L. tolantongo sp. nov. & 0.012 & 0.009 & 0.015 & 0.012 & 0.003 & 0.003 & 0.006 & 0.009 & & \\
10. Ara0182 - L. tolantongo sp. nov. & 0.017 & 0.015 & 0.021 & 0.017 & 0.009 & 0.009 & 0.006 & 0.014 & 0.006 & \\
11. Ara0175 - L. tolantongo sp. nov. & 0.025 & 0.021 & 0.029 & 0.024 & 0.015 & 0.015 & 0.018 & 0.021 & 0.012 & 0.015 \\
\hline
\end{tabular}

In recent studies, molecular evidence has suggested that the known diversity within the genus Loxosceles could be highly underestimated (Binford et al. 2008; Duncan et al. 2010; Planas \& Ribera 2014, 2015; Tahami et al. 2017; Valdez-Mondragón et al. 2019). One important factor leading to the underestimation is widespread intraspecific variation in sexual structures, mainly in the seminal receptacles of the females (Figs 36-43), as was noted in this work and previously by Brignoli (1968), Gertsch \& Ennik (1983), and recently by Valdez-Mondragón et al. (2018b, 2019) in the case of the species from Mexico. However, sexual structures such as the male palps remain a good character for species identification because of their little morphological variation in comparison with the seminal receptacles of the females (ValdezMondragón et al. 2018a, 2018b, 2019). It is important to consider that male palps may be remarkably similar, as indicated for L. tolantongo sp. nov and L. jaca (which showed slight differences), which can also make species identifications difficult, thus contributing to such underestimations. Although $L$. tolantongo sp. nov. morphologically resembles $L$. jaca, the new species could be diagnosed based on the sexual characters of the male palps (Figs 20-25) and the seminal receptacles of the females (Figs 28, 36-39). Furthermore, molecular markers provided additional evidence to delimit the new species within an integrative taxonomic context. Identifying morphologically inseparable cryptic or sibling species 
requires a new set of taxonomic tools, including DNA and additional sources of evidence (integrative taxonomy) (Jarman \& Elliott 2000; Witt \& Hebert 2000; DeSalle et al. 2005; Hebert et al. 2003, 2004; Bickford et al. 2007; Hamilton et al. 2011, 2014, 2016; Ortiz \& Francke 2016, Valdez-Mondragón et al. 2018a, 2018b, 2019).

As was mentioned by Hamilton et al. (2011), we can rarely delimit species based only on molecular data, and that is why, in addition to the molecular evidence, the geographical data provides information to delimit these species. Loxosceles jaca and L. tolantongo sp. nov. were found in different localities, Cardonal and Jacala, Hidalgo, respectively. The type locality of the new species is located in the Tolantongo Canyon, $500 \mathrm{~m}$ deep, where the Tolantongo river is located, which can serve as a geographic barrier for Loxosceles spiders that usually have limited dispersions (Sandidge \& Hopwood 2005; Binford et al. 2008; Vetter 2008, 2015; Foelix 2011). Also, both species were found in different vegetation types: L. tolantongo sp. nov. was found in a xerophytic forest between 1315 and $1481 \mathrm{~m}$ a.s.l., under

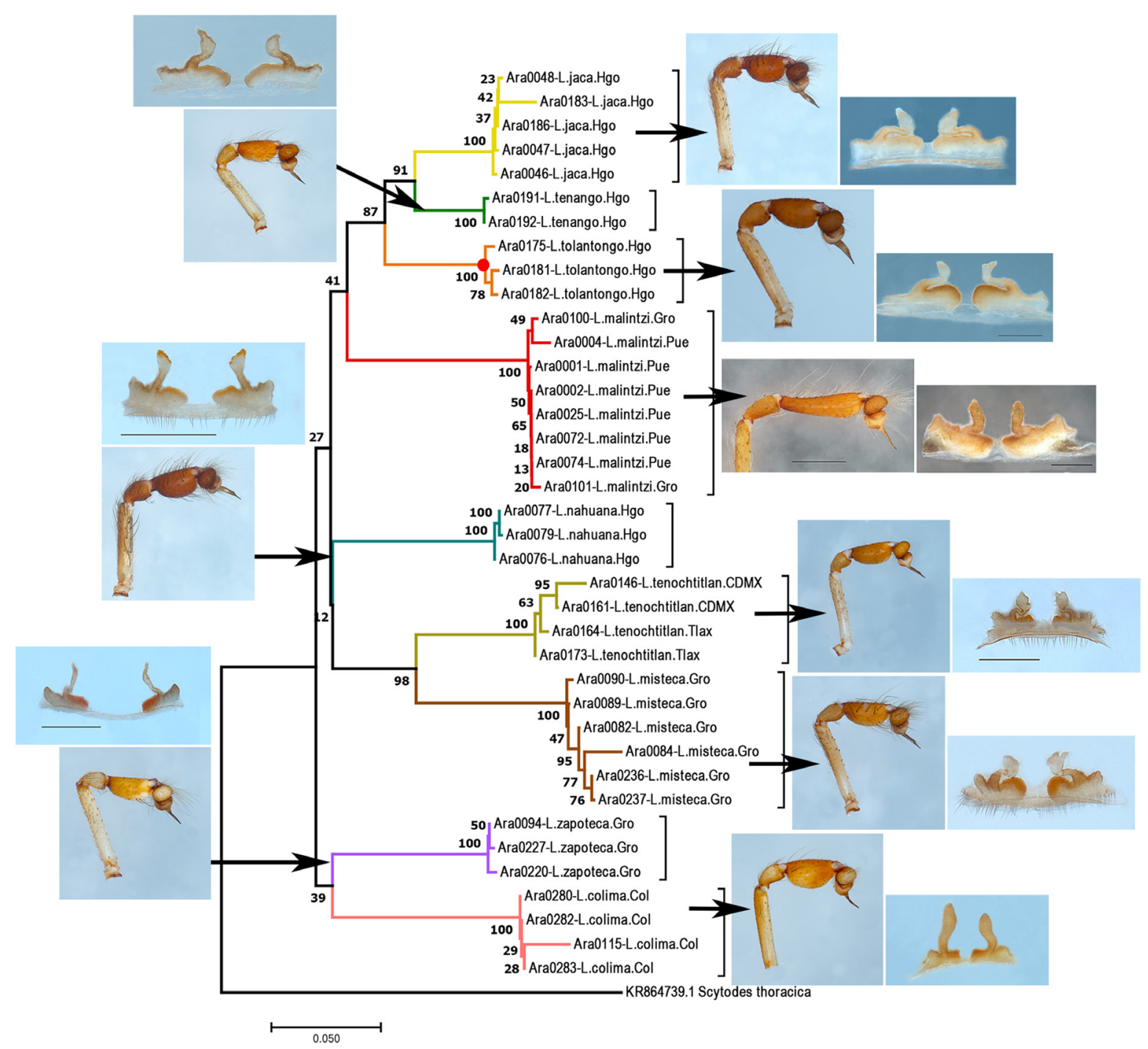

Fig. 52. Neighbor joining tree constructed from $\mathrm{COI}$ data of nine species of Loxosceles Heineken \& Lowe, 1832 from Mexico. Colors of branches indicate different species. Numbers on nodes are bootstrap support values. Red circle at node represents Loxosceles tolantongo sp. nov. 
rocks and dry agave plants, whereas $L$. jaca was found in shrub vegetation at $1290 \mathrm{~m}$ a.s.l. , mainly within dry agave leaves. The vegetation type seems to play an important role in the ecological niche and delimitation of distribution for some species of Loxosceles from Mexico, as was demonstrated by Valdez-Mondragón et al. (2019) with the ecological niche modeling of L. tenochtitlan, a widespread species from the central region of Mexico.

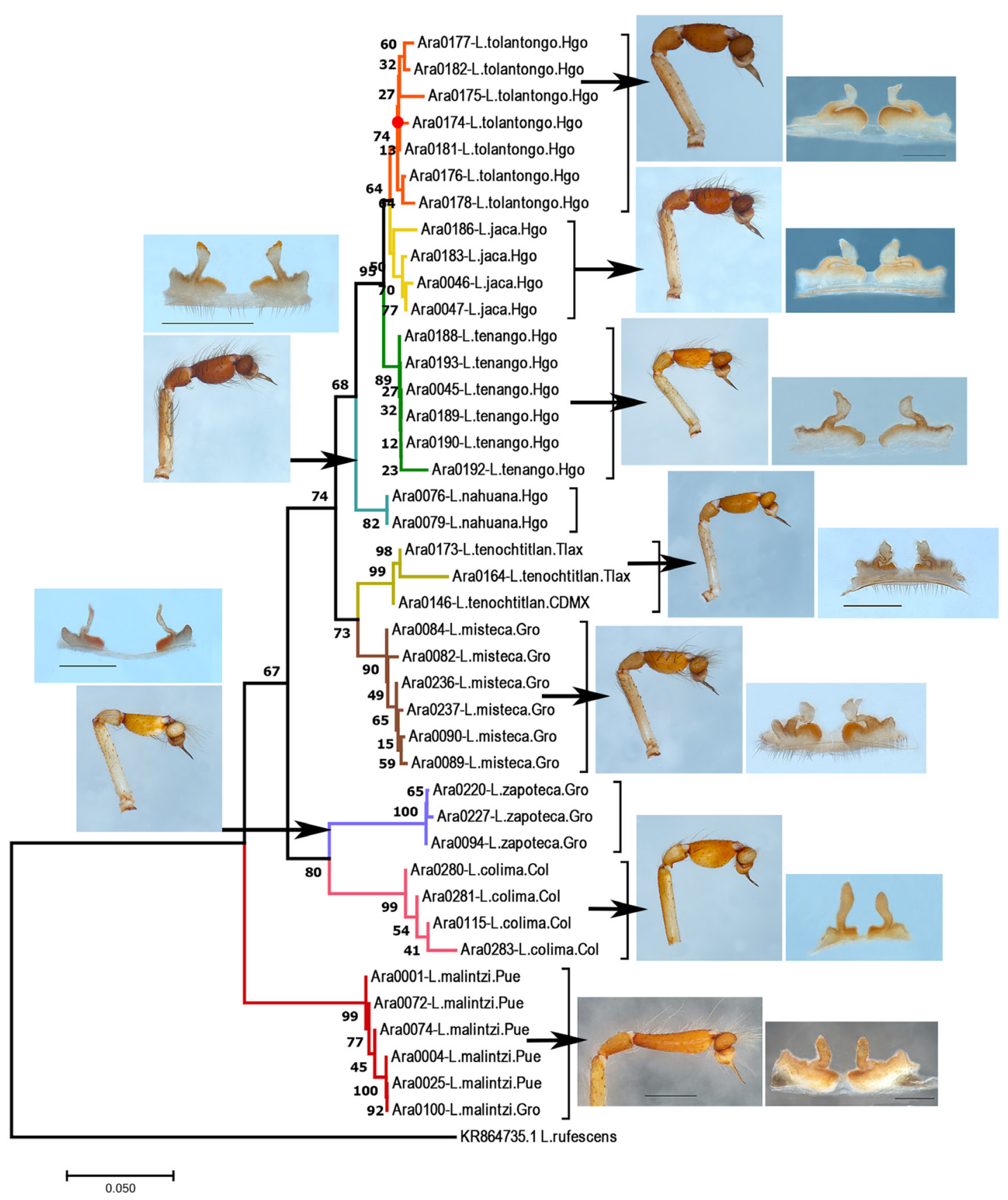

Fig. 53. Neighbor joining tree of ITS2 data of nine species of Loxosceles Heineken \& Lowe, 1832 from Mexico. Colors of branches indicate different species. Numbers at nodes represent bootstrap support values. Red circle at node represent Loxosceles tolantongo sp. nov. 
Planas \& Ribera $(2014,2015)$ found genetic distances between species of Loxosceles from the Canary Islands to be $>12 \%$ using CO1, whereas Tahami et al. (2017) found genetic distances between species from the Middle East ranging from 17.5 to $20.6 \%$ for $C O 1$. In this work, the genetic distances were over $15 \%$ between the different species. They also reported average low genetical distances inside the same species $(0.26 \%$ and less than $1 \%)$ and in this work the intraspecific genetic distances are low

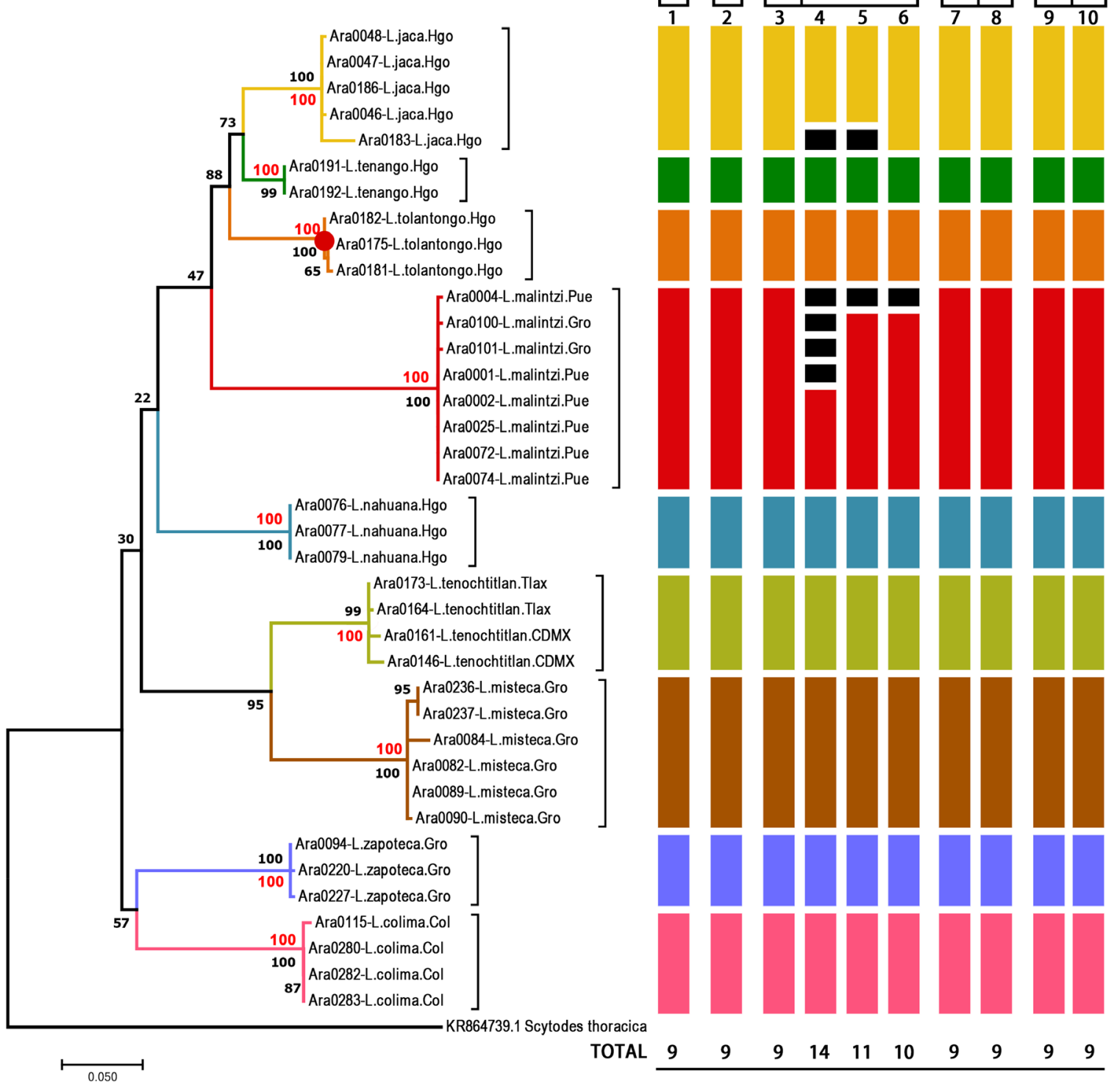

Fig. 54. Maximum likelihood tree inferred from COI gene of species of Loxosceles Heineken \& Lowe, 1832 from Mexico. Colors of branches and bars indicate different species. Numbers above bars represent the delimitation methods: $1=$ morphology $(\mathrm{M}) ; 2=$ neighbor joining $(\mathrm{NJ}) ; 3=\mathrm{ABGD}$ with initial partitions (IP); 4-6 = ABGD with recursive partitions (RP); $7=$ GMYC yule analysis; $8=$ GMYC coalescent analysis; $9=$ bPTP with ML; $10=$ bPTP with IB. Numbers below bars represent species recovered for each delimitation method. Red numbers on branches correspond to Bayesian posterior probabilities, black numbers are bootstrap support values from the ML analysis. 
$(<1 \%)$ (Tables 3-4; Fig. 52). The corrected genetic $p$-distances showed that CO1 performed better for species delimitation than ITS2 (Figs. 52-55). Agnarsson (2010) concluded that ITS2 was insufficient to solve the relationships between closely related species, but also indicated that ITS2 is an easily amplified and sequenced marker for use in spider phylogeny despite its limits at lower taxonomic levels.

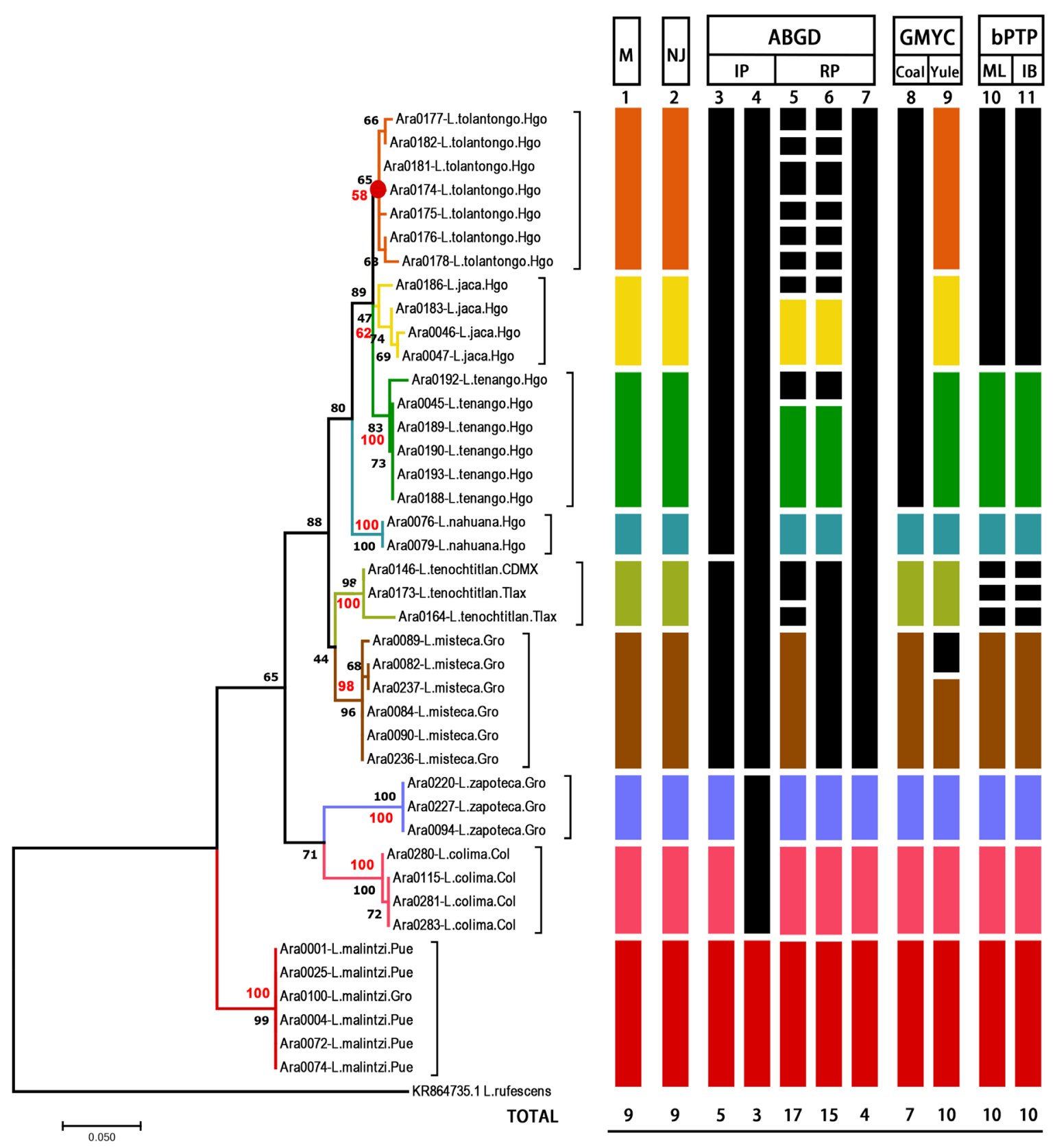

Fig. 55. Maximum likelihood tree inferred from ITS2 gene of species of Loxosceles Heineken \& Lowe, 1832 from Mexico. Colors of branches and bars indicate different species. Numbers above bars represent the delimitation methods: $1=$ morphology (M); $2=$ neighbor joining (NJ); 3-4 = ABGD with initial partitions (IP); 5-7 = ABGD with recursive partitions (RP); $8=$ GMYC yule analysis; $9=$ GMYC coalescent analysis; $10=$ bPTP with ML; $11=$ bPTP with IB. Numbers below bars represent species recovered for each delimitation method. Red numbers on branches correspond to Bayesian posterior probabilities, black numbers are bootstrap support values from the ML analysis. 
The uses of the ABGD species delimitation method are recursive partitioning, with a range of prior intraspecific divergence and relative gap width to estimate the threshold between intra- and interspecific variation which intends to produce species-level groupings (Ortiz \& Francke 2016). However, this species delimitation method is sensitive to sampling effect, as was demonstrated in the spider genera Aphonopelma Pocock, 1901 and Bonnetina Vol, 2000 from North America by Hamilton et al. (2014) and Ortiz \& Francke (2016), respectively, tending to give moderately over-splitting solutions as was the case of our work (Fig. 55). PTP is similar to GMYC, but uses substitution calibrated (not ultrametric)

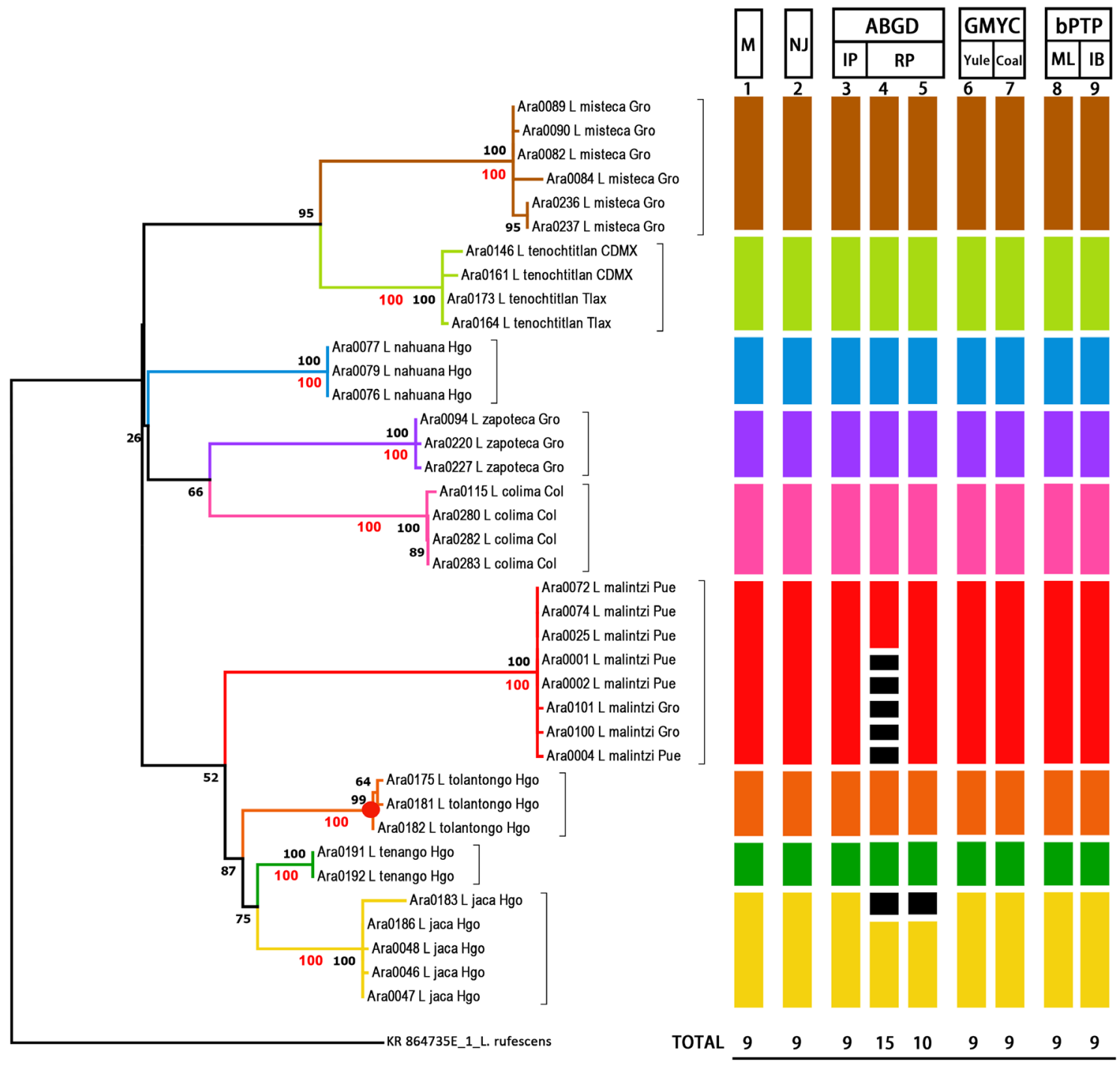

$\underset{0.020}{\longrightarrow}$

Fig. 56. Maximum likelihood tree inferred from the concatenated matrix $(C O 1+I T S 2)$ of species of Loxosceles Heineken \& Lowe, 1832 from Mexico. Colors of branches and bars indicate different species. Numbers above bars represent the delimitation methods: $1=$ morphology $(\mathrm{M}) ; 2=$ neighbor joining (NJ); $3=$ ABGD with initial partitions (IP); 4-5 = ABGD with recursive partitions (RP); $6=$ GMYC yule analysis; 7 = GMYC coalescent analysis; 8 bPTP with ML; $9=$ bPTP with IB. Numbers below bars represent species recovered for each delimitation method. Red numbers correspond to Bayesian posterior probabilities, black numbers are bootstrap support values from the ML analysis. 
trees to avoid the potential flaws in constructing time-calibrated phylogenies, as was proposed by Zhang et al. (2013).

The work of Cao et al. (2016) with the spider genus Pseudopoda Jäger, 2000 (Sparassidae Bertkau,1872) suggested using concatenated fragments $C O 1+I T S 2$, which identifies and diagnoses species in a more appropriate way than the separated mitochondrial barcodes. In this work, the concatenated matrix showed that all species delimitation methods were congruent with the morphology, recovering L. tolantongo sp. nov. as a separated species (Figs 54-56). Carstens et al. (2013) suggested that researchers should apply a wide range of species delimitation analyses to their data and place their trust in delimitations that are congruent across methods. Using several species delimitation methods, incongruence across the different results is evidence of a difference in the power to detect cryptic lineages across one or more of the approaches used to delimit species and could indicate that assumptions of one or more of the methods have been violated. In these cases the assumptions for species delimitations should be conservative (Carstens et al. 2013). In this work, the different molecular species delimitation methods and their variants were congruent and consistent to separate $L$. tolantongo sp. nov. of $L$. jaca $+L$. tenango. Loxosceles tolantongo sp. nov. is considered a unique species for four reasons: 1) it can be diagnosed and distinguished by morphological characters (male palps mainly); 2) the high genetic $p$-distances with $\mathrm{COI}(>10 \%) ; 3)$ the four different molecular species delimitation methods were congruent under

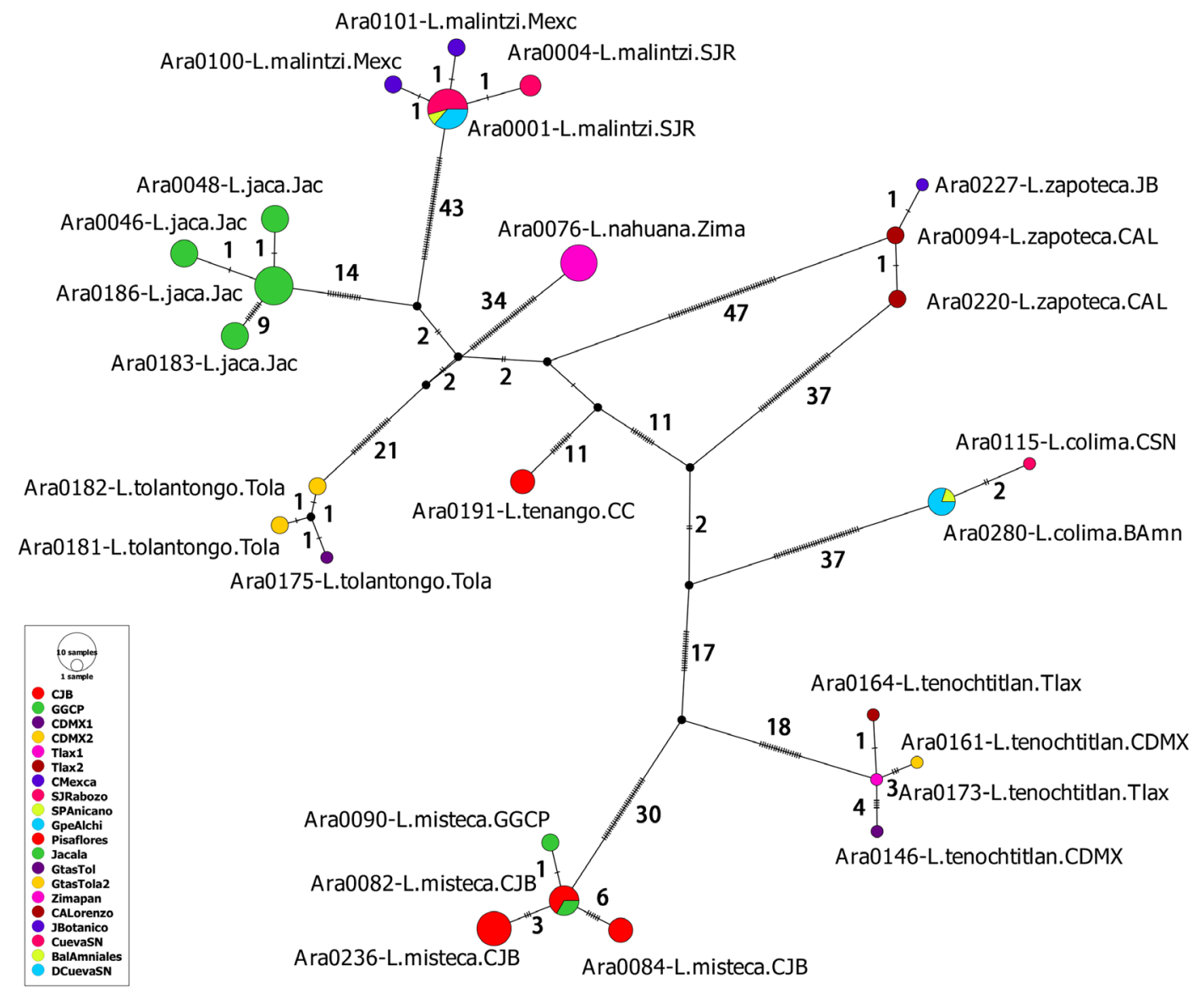

Fig. 57. Haplotype network from the $\mathrm{CO} 1$ data obtained with TCS using PopArt. Each circle represents the haplotypes found in nine species of Loxosceles Heineken \& Lowe, 1832 from Mexico. Numbers on branches indicate the number of mutations between haplotypes. 
$\mathrm{CO} 1$ and $\mathrm{CO} 1+\mathrm{ITS} 2$ (concatenated matrix); 4) under CO1 and CO1+ITS2, L. tolantongo sp. nov. is a putative sister group of $L$. jaca $+L$. tenango.

Although the new species described herein has a small range of occurrence, it is considered as not threatened. The Tourist Center Grutas de Tolantongo, which belongs to the Socieded Cooperativa Ejidal Grutas Tolantongo (Cooperative Ejido Society of the Tolantongo Grottos), has managed to preserve much of the resort and the ejido land around it in its natural state, preserving many native species distributed in the region.

\section{Acknowledgements}

Dr. Alejandro Valdez-Mondragón (AVM) (second author) thanks the program Cátedras CONACyT, Consejo Nacional de Ciencia y Tecnología (CONACyT), Mexico, for scientific support of the project No. 59: "Laboratorio Regional de Biodiversidad y Cultivo de Tejidos Vegetales (LBCTV) del Instituto de Biología, Universidad Nacional Autónoma de México (IBUNAM), sede Tlaxcala". AVM also thanks SEP-CONACyT for financial support of the project Basic Science (Ciencia Básica) 2016, No. 282834: “Arañas de Importancia Médica: Taxonomía integrativa basada en evidencia molecular y morfológica para la delimitación de las especies mexicanas de arañas violinistas del género Loxosceles Heineken \& Lowe (Araneae, Sicariidae)-Etapa 1". The first author thanks Posgrado en Ciencias Biológicas of Centro Tlaxcala de Biología de la Conducta (CTBC), Universidad Autónoma de Tlaxcala (UATx), for educational support, and CONACyT for scholarship support during the Master's of Biological Science. Thanks to the Secretaría de Fomento Agropecuario del Estado de Tlaxcala (SEFOA) and the Government of the state of Tlaxcala for the facilities and support to conduct this research. We thank Dr. Oscar F. Francke, Curator of the Colección Nacional de Arácnidos (CNAN), IBUNAM, Mexico City, for the loan of the collection of Loxosceles specimens of the CNAN. We also thank the students of the CNAN and Laboratory of Arachnology (LATLAX), IBUNAM, Tlaxcala, for their help in the field and processing of the material in the laboratory. To Mayra R. Cortez Roldán for her help with the distribution map. To Cheryl Harleston for the English language review of the manuscript. The specimens were collected under Scientific Collector Permit FAUT-0309 from the Secretaría de Medio Ambiente y Recursos Naturales (SEMARNAT) to AVM.

\section{References}

Agnarsson I. 2010. The utility of ITS2 in spider phylogenetics: notes on prior work and an example from Anelosimus. The Journal of arachnology 38 (2): 377-382. https://doi.org/10.1636/B10-01.1

Astrin J.J. \& Stüben P.E. 2008. Phylogeny in cryptic weevils: molecules, morphology and new genera of western Palaearctic Cryptorhynchinae (Coleoptera: Curculionidae). Invertebrate Systematics 22 (5): 503-522. https://doi.org/10.1071/IS07057

Bickford D., Lohman D.J., Sodhi N.S., Ng P.K., Meier R., Winker K., Ingram K.K. \& Das I. 2007. Cryptic species as a window on diversity and conservation. Trends in Ecology and Evolution 22 (3): 148-155. https://doi.org/10.1016/j.tree.2006.11.004

Binford G.J., Callahan M.S., Bodner M.R., Rynerson M.R., Berea-Núñez P., Ellison C.E \& Duncan R.P. 2008. Phylogenetic relationships of Loxosceles and Sicarius spiders are consistent with Western Gondwanan vicariance. Molecular Phylogenetics and Evolution 49 (2): 538-553.

https://doi.org/10.1016/j.ympev.2008.08.003

Brignoli P. 1968. Note sugli Scytodidae d'Italia e Malta (Araneae). Fragmenta Entomologica 6: 121166. 
Cao X., Liu J., Chen J., Zheng G., Kuntner M. \& Agnarsson I. 2016. Rapid dissemination of taxonomic discoveries based on DNA barcoding and morphology. Scientific Reports 6: 37066.

https://doi.org/10.1038/srep37066

Carstens B.C., Pelletier T.A., Reid N.M. \& Satler J.D. 2013. How to fail at species delimitation. Molecular Ecology 22: 4369-4383. https://doi.org/10.1111/mec.12413

Clement M., Posada D. \& Crandall K.A. 2000. TCS: a computer program to estimate gene genealogies. Molecular Ecology 9 (10): 1657-1659. https://doi.org/10.1046/j.1365-294x.2000.01020.x

DeSalle R., Egan M.G. \& Siddall M. 2005. The unholy trinity: taxonomy, species delimitation and DNA barcoding. Philosophical Transactions of the Royal Society of London, B, Biological Sciences 360 (1462): 1905-1916. https://doi.org/10.1098/rstb.2005.1722

Duncan R.P., Rynerson M.R., Ribera C. \& Binford G.J. 2010. Diversity of Loxosceles spiders in Northwestern Africa and molecular support for cryptic species in the Loxosceles rufescens lineage. Molecular Phylogenetics and Evolution 55 (1): 234-248. https://doi.org/10.1016/j.ympev.2009.11.026

Drummond A.J., Suchard M.A., Xie D. \& Rambaut A. 2012. Bayesian phylogenetics with BEAUti and the BEAST 1.7. Molecular Biology and Evolution 29 (8): 1969-1973.

https://doi.org/10.1093/molbev/mss075

Foelix R.F. 2011. Biology of Spiders. Harvard University Press, Cambridge, Massachusetts.

Folmer M., Black W., Lutz R. \& Vrijenhoek R. 1994. DNA primers for amplification of mitochondrial cytochrome c oxidase subunit I from diverse metazoan invertebrates. Molecular Marine Biology and Biotechnology 3: 294-299.

Fujisawa T. \& Barraclough T.G. 2013. Delimiting species using single-locus data and the Generalized Mixed Yule Coalescent approach: a revised method and evaluation on simulated data sets. Systematic Biology 62 (5): 707-724. https://doi.org/10.1093/sysbio/syt033

Fukushima C.S., Gonçalves de Andrade R.M. \& Bertani R. 2017. Two new Brazilian species of Loxosceles Heinecken \& Lowe, 1832 with remarks on amazonica and rufescens groups (Araneae, Sicariidae). ZooKeys 667: 67-94. https://doi.org/10.3897/zookeys.667.11369

Gertsch W.J. 1967. The spider genus Loxosceles in South America (Araneae, Scytodidae). Bulletin of the American Museum of Natural History 136: 117-174.

Gertsch W.J. 1958. The spider genus Loxosceles in North America, Central America, and the West Indies. American Museum Novitates 1907: 1-46.

Gertsch W.J. 1973. A report on cave spiders from Mexico and Central America. Association for Mexican Cave Studies Bulletin 5: 141-163.

Gertsch W.J. \& Ennik F. 1983. The spider genus Loxosceles in North America, Central America, and the West Indies (Araneae, Loxoscelidae). Bulletin of the American Museum of Natural History 175: 264-360.

Hall T.A. 1999. BioEdit: a user-friendly biological sequence alignment editor and analysis program for Windows 95/98/NT. Nucleic Acids Symposium Series 41: 95-98.

Hamilton C.A., Formanowicz D.R. \& Bond J.E. 2011. Species delimitation and phylogeography of Aphonopelma hentzi (Araneae, Mygalomorphae, Theraphosidae): cryptic diversity in North American tarantulas. PLoS ONE 6 (10): e26207. https://doi.org/10.1371/journal.pone.0026207

Hamilton C.A., Hendrixson B.E., Brewer M.S. \& Bond J.E. 2014. An evaluation of sampling effects on multiple DNA barcoding methods leads to an integrative approach for delimiting species: A case 
study of the North American tarantula genus Aphonopelma (Araneae, Mygalomorphae, Theraphosidae). Molecular Phylogenetics and Evolution 71: 79-93. https://doi.org/10.1016/j.ympev.2013.11.007

Hamilton C.A., Hendrixson B.E. \& Bond J.E. 2016. Taxonomic revision of the tarantula genus Aphonopelma Pocock, 1901 (Araneae, Mygalomorphae, Theraphosidae) within the United States. ZooKeys 560: 1-340. https://doi.org/10.3897/zookeys.560.6264

Hebert P.D.N., Cywinska A., Ball S.L. \& Dewaard J.R. 2003. Biological identifications through DNA barcodes. Proceedings of the Royal Society, B, Biological Sciences 270 (1512): 313-321. https://doi.org/10.1098/rspb.2002.2218

Hebert P.D.N., Penton E.H., Burns J.M., Janzen D.H. \& Hallwachs W. 2004. Ten species in one: DNA barcoding reveals cryptic species in the Neotropical skipper butterfly Astraptes fulgerator. Proceedings of the National Academy of Sciences of the United States of America 101 (41): 14812-14817. https://doi.org/10.1073/pnas.0406166101

Huber B.A. 2003. Rapid evolution and species-specificity of arthropod genitalia: fact or artifact? Organisms Diversity \& Evolution 3 (1): 63-71. https://doi.org/10.1078/1439-6092-00059

Huber B.A., Rheims C.A. \& Brescovit A.D. 2005. Speciation without changes in genital shape: a case study on Brazilian pholcid spiders (Araneae: Pholcidae). Zoologischer Anzeiger 243 (4): 273-279. https://doi.org/10.1016/j.jcz.2004.12.001

Huber B.A. \& Dimitrov D. 2014. Slow genital and genetic but rapid non-genital and ecological differentiation in a pair of spider species (Araneae, Pholcidae). Zoologischer Anzeiger 253 (5): 394-403. https://doi.org/10.1016/j.jcz.2014.04.001

Jarman S.N. \& Elliott N.G. 2000. DNA evidence for morphological and cryptic Cenozoic speciations in the Anaspididae 'living fossils' from the Triassic. Journal of Evolutionary Biology 13 (4): 624-633. https://doi.org/10.1046/j.1420-9101.2000.00207.x

Ji Y.-J., Zhang D.-X., He L.-J. 2003. Evolutionary conservation and versatility of a new set of primers for amplifying the ribosomal internal transcribed spacer regions in insects and other invertebrates. Molecular Ecology Notes 3 (4): 581-585. https://doi.org/10.1046/j.1471-8286.2003.00519.x

Kapli P., Lutteropp S., Zhang J., Kobert K., Pavlidis P., Stamatakis A. \& Flouri T. 2017. Multi-rate Poisson tree processes for single-locus species delimitation under maximum likelihood and Markov chain Monte Carlo. Bioinformatics 33 (11): 1630-1638. https://doi.org/10.1093/bioinformatics/btx025

Katoh K. \& Toh H. 2008. Recent developments in the MAFFT multiple sequence alignment program. Briefings in Bioinformatics 4 (9): 286-298. https://doi.org/10.1093/bib/bbn013

Kearse M., Moir R., Wilson A., Stones-Havas S., Cheung M., Sturrock S., Buxton S., Cooper A., Markowitz S., Duran C., Thierer T., Ashton B., Meintjes P. \& Drummond A. 2012. Geneious Basic: an integrated and extendable desktop software platform for the organization and analysis of sequence data. Bioinformatics 28 (12): 1647-1649. https://doi.org/10.1093/bioinformatics/bts199

Leigh J.W. \& Bryant D. 2015. PopArt: full-feature software for haplotype network construction. Methods in Ecology and Evolution 6 (9): 1110-1116. https://doi.org/10.1111/2041-210X.12410

Monaghan M.T., Wild R., Elliot M., Fujisawa T., Balke M., Inward D.J. \& Vogler A.P. 2009. Accelerated species inventory on Madagascar using coalescent-based models of species delineation. Systematic Biology 58 (3): 298-311. https://doi.org/10.1093/sysbio/syp027

Ortiz D. \& Francke O.F. 2016. Two DNA barcodes and morphology for multi-method species delimitation in Bonnetina tarantulas (Araneae: Theraphosidae). Molecular Phylogenetics and Evolution 101: 176193. https://doi.org/10.1016/j.ympev.2016.05.003 
Planas E. \& Ribera C. 2014. Uncovering overlooked island diversity: colonization and diversification of the medically important spider genus Loxosceles (Arachnida: Sicariidae) on the Canary Islands. Journal of Biogeography 41 (7): 1255-1266. https://doi.org/10.1111/jbi.12321

Planas E. \& Ribera C. 2015. Description of six new species of Loxosceles (Araneae: Sicariidae) endemic to the Canary Islands and the utility of DNA barcoding for their fast and accurate identification. Zoological Journal of the Linnean Society 174 (1): 47-73. https://doi.org/10.1111/zoj.12226

Pons J., Barraclough T.G. \& Gomez-Zurita J. 2006. Sequence based species delimitation for the DNA taxonomy of undescribed insects. Systematic Biology 55 (4): 595-609.

https://doi.org/10.1080/10635150600852011

Posada D., Buckley T.R. 2004. Model selection and model averaging in phylogenetics: advantages of Akaike information criterion and Bayesian approaches over likelihood ratio tests. Systematic Biology 53 (5): 793-808. https://doi.org/10.1080/10635150490522304

Proudlove G. \& Wood P.J. 2003. The blind leading the blind: cryptic subterranean species and DNA taxonomy. Trends in Ecology and Evolution 18 (6): 272-273.

https://doi.org/10.1016/S0169-5347(03)00095-8

Puillandre N., Lambert A., Brouillet S. \& Achaz G. 2012. ABGD, Automatic Barcode Gap Discovery for primary species delimitation. Molecular Ecology 21 (8): 1864-1877.

https://doi.org/10.1111/j.1365-294X.2011.05239.x

Rambaut A. \& Drummond A.J. 2014. TRACER, MCMC Trace Analysis Tool Version 1.6. University of Edinburgh/University of Auckland, Edinburgh/Auckland.

Ronquist F. \& Huelsenbeck J.P. 2003. MrBayes 3: Bayesian phylogenetic inference under mixed models. Bioinformatics 19 (12): 1572-1574. https://doi.org/10.1093/bioinformatics/btg180

Sandidge J.S. \& Hopwood J.L. 2005. Brown recluse spiders: a review of biology, life history and pest management. Transactions of the Kansas Academy of Science 108 (3): 99-108.

https://doi.org/10.1660/0022-8443(2005)108[0099:BRSARO]2.0.CO;2

Tahami M.S., Zamani A., Sadeghil S. \& Ribera C. 2017. A new species of Loxosceles Heineken \& Lowe, 1832 (Araneae: Sicariidae) from Iranian caves. Zootaxa 4318(2): 377-387.

https://doi.org/10.11646/zootaxa.4318.2.10

Valdez-Mondragón A. \& Francke O.F. 2015. Phylogeny of the spider genus Ixchela Huber, 2000 (Araneae: Pholcidae) based on morphological and molecular evidence (CO1 and 16S), with a hypothesized diversification in the Pleistocene. Zoological Journal of the Linnean Society 175: 20-58. https://doi.org/10.1111/zoj.12265

Valdez-Mondragón A., Cortez-Roldán M.R., Juárez-Sánchez A.R., Solís-Catalán K.P. \& NavarroRodríguez C.I. 2018a. Arañas de Importancia Medica: Arañas violinistas del género Loxosceles en México: ¿que sabemos acerca de su distribución y biología hasta ahora? Boletín de la Asociación Mexicana de Sistemática de Artrópodos (AMXSA) 2 (1): 14-24.

Valdez-Mondragón A., Cortez-Roldán M.R., Juárez-Sánchez A.R. \& Solís-Catalán K.P. 2018b. A new species of Loxosceles Heineken \& Lowe (Araneae, Sicariidae), with updated distribution records and biogeographical comments for the species from Mexico, including a new record of Loxosceles rufescens (Dufour). ZooKeys 802: 39-66. https://doi.org/10.3897/zookeys.802.28445

Valdez-Mondragón A., Navarro-Rodríguez C.I., Solís-Catalán K.P., Cortez-Roldán M.R. \& JuárezSánchez A.R. 2019. Under an integrative taxonomic approach: the description of a new species of the genus Loxosceles (Araneae, Sicariidae) from Mexico City. ZooKeys 892: 93-133.

https://doi.org/10.3897/zookeys.892.39558 
Vetter R.S. 2008. Spiders of the genus Loxosceles (Araneae, Sicariidae): a review of biological, medical and psychological aspects regarding envenomations. Journal of Arachnology 36 (1): 150-163. https://doi.org/10.1636/RSt08-06.1

Vetter R.S. 2015. The Brown Recluse Spider. Cornell University Press / Comstock Publishing Associates, Ithaca/London.

Witt J.D.S. \& Hebert P.D.N. 2000. Cryptic species diversity and evolution in the amphipod genus Hyalella within central glaciated North America: a molecular phylogenetic approach. Canadian Journal of Fisheries and Aquatic Sciences 57 (4): 687-698. https://doi.org/10.1139/f99-285

World Spider Catalog. 2020. World Spider Catalog. Version 20.0. Natural History Museum Bern. Available from http://wsc.nmbe.ch [accessed 20 Jan. 2020]. https://doi.org/10.24436/2

Zhang J., Kapli P., Pavlidis P. \& Stamatakis A. 2013. A general species delimitation method with applications to phylogenetic placements. Bioinformatics 29 (22): 2869-2876.

https://doi.org/10.1093/bioinformatics/btt499

Manuscript received: 14 April 2020

Manuscript accepted: 3 July 2020

Published on: 19 August 2020

Topic editor: Rudy C.A.M. Jocqué

Desk editor: Radka Rosenbaumová

Printed versions of all papers are also deposited in the libraries of the institutes that are members of the EJT consortium: Muséum national d'histoire naturelle, Paris, France; Meise Botanic Garden, Belgium; Royal Museum for Central Africa, Tervuren, Belgium; Royal Belgian Institute of Natural Sciences, Brussels, Belgium; Natural History Museum of Denmark, Copenhagen, Denmark; Naturalis Biodiversity Center, Leiden, the Netherlands; Museo Nacional de Ciencias Naturales-CSIC, Madrid, Spain; Real Jardín Botánico de Madrid CSIC, Spain; Zoological Research Museum Alexander Koenig, Bonn, Germany; National Museum, Prague, Czech Republic. 